by Martin J. Head ${ }^{l *}$, Will Steffen ${ }^{2}$, David Fagerlind ${ }^{3}$, Colin N. Waters ${ }^{4}$, Clement Poirier ${ }^{5}$,

Jaia Syvitski, Jan A. Zalasiewicz ${ }^{4}$, Anthony D. Barnosky ${ }^{7}$, Alejandro Cearreta ${ }^{8}$,

Catherine Jeandel ${ }^{9}$, Reinhold Leinfelder ${ }^{10}$, J.R. McNeill ${ }^{11}$, Neil L. Rose ${ }^{12}$,

Colin Summerhayes ${ }^{13}$, Michael Wagreich ${ }^{14}$, and Jens Zinke ${ }^{4}$

\title{
The Great Acceleration is real and provides a quantitative basis for the proposed Anthropocene Series/Epoch
}

\author{
${ }^{1}$ Department of Earth Sciences, Brock University, 1812 Sir Isaac Brock Way, St. Catharines, Ontario L2S 3A1, Canada; \\ *Corresponding author, E-mail: mjhead@brocku.ca \\ ${ }^{2}$ Fenner School of Environment and Society, Australian National University, Canberra, ACT 0200, Australia \\ ${ }^{3}$ Stockholm Resilience Centre, Stockholm University, Kräftriket 2B, SE-10691, Sweden \\ ${ }^{4}$ School of Geography, Geology and the Environment, University of Leicester, University Road, Leicester LE1 7RH, UK \\ ${ }^{5}$ Normandie Université, UNICAEN, UNIROUEN, CNRS, M2C, 14000 Caen, France \\ ${ }^{6}$ INSTAAR, University of Colorado, Boulder, CO 80309, USA \\ ${ }^{7}$ Jasper Ridge Biological Preserve, Stanford University, Stanford, CA 94305, USA \\ ${ }^{8}$ Departamento de Geología, Facultad de Ciencia y Tecnología, Universidad del País Vasco UPV/EHU, Apartado 644, 48080 Bilbao, Spain \\ ${ }^{9}$ LEGOS, Université de Toulouse, CNES, CNRS, IRD, UPS, 14 avenue Édouard Belin, 31400 Toulouse, France \\ ${ }^{10}$ Department of Geological Sciences, Freie Universität Berlin, Malteserstr. 74-100/D, 12249 Berlin, Germany \\ ${ }^{11}$ Georgetown University, Washington DC, USA \\ ${ }^{12}$ Environmental Change Research Centre, Department of Geography, University College London, Gower Street, London WC1E 6BT, UK \\ ${ }^{13}$ Scott Polar Research Institute, University of Cambridge, Lensfield Road, Cambridge CB2 1ER, UK \\ ${ }^{14}$ Department of Geodynamics and Sedimentology, University of Vienna, A-1090 Vienna, Austria
}

(Received: April 7, 2021; Revised accepted: October 7, 2021)

https://doi.org/10.18814/epiiugs/2021/021031

The Anthropocene was conceptualized in 2000 to reflect the extensive impact of human activities on our planet, and subsequent detailed analyses have revealed a substantial Earth System response to these impacts beginning in the mid-20 $0^{\text {th }}$ century. Key to this understanding was the discovery of a sharp upturn in a multitude of global socio-economic indicators and Earth System trends at that time; a phenomenon termed the 'Great Acceleration'. It coincides with massive increases in global human-consumed energy and shows the Earth System now on a trajectory far exceeding the earlier variability of the Holocene Epoch, and in some respects the entire Quaternary Period. The evaluation of geological signals similarly shows the mid-20 $20^{\text {th }}$ century as representing the most appropriate inception for the Anthropocene. A recent mathematical analysis has nonetheless challenged the significance of the original Great Acceleration data. We examine this analytical approach and reiterate the robustness of the original data in supporting the Great Acceleration, while emphasizing that intervals of rapid growth are inevitably time-limited, as recognised at the outset. Moreover, the exceptional magnitude of this growth remains undeniable, reaffirming the centrality of the Great Acceleration in justifying a formal chronostratigraphic Anthropocene at the rank of series/epoch.

\section{Introduction}

The Anthropocene was proposed in 2000 from the perspective of Earth System science to reflect the profound impact of human activities on our planet, with a suggested onset in the latter part of the $18^{\text {th }}$ century (Crutzen and Stoermer, 2000; Crutzen, 2002). The term had in fact been used informally, and for a limited time, by biologist Eugene Stoermer in the 1980s. Stoermer had not been interested in pursuing its further use and was clear that Crutzen should be recognised as the sole originator of the term Anthropocene and its concept as we essentially use it today.

Pfister $(1992,1994)$ had already drawn attention to socio-economic shifts in the mid- $20^{\text {th }}$ century that he labelled 'the 1950 s syndrome' - but with regard to Europe rather than the planet as a whole. In 2004, an interval around the year 1950 was discovered within the Earth System science community to represent the most pronounced upward deflections of numerous global socio-economic indicators and Earth System trends, including those that can be recognized in geological strata (Steffen et al., 2004). The deflection became known as the 'Great Acceleration' (Steffen et al., 2007) echoing Karl Polanyi's 1944 holistic societal analysis The Great Transformation. The Great Acceleration expressed a similarly holistic, comprehensive and interlinked depiction of post-1950 changes covering socio-economic factors and biophysical processes as well as environmental and climatic 
a) Present ratified scheme

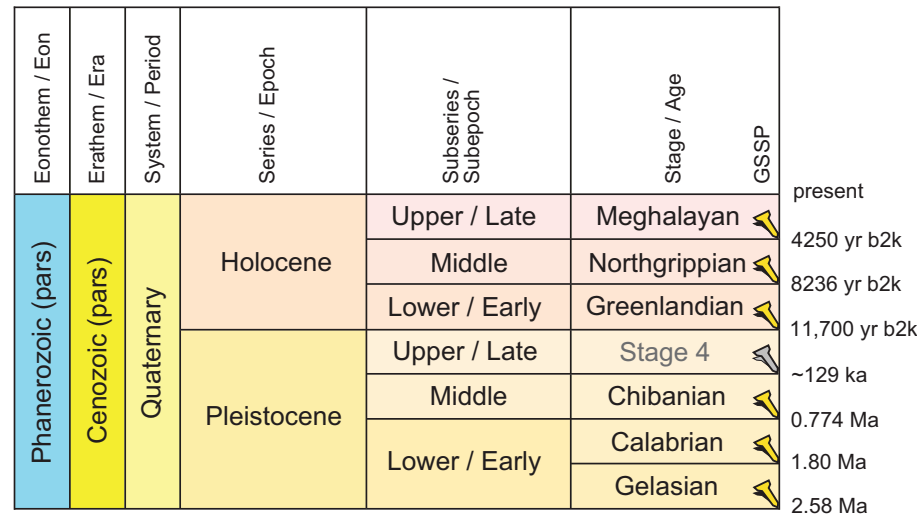

b) Anthropocene added

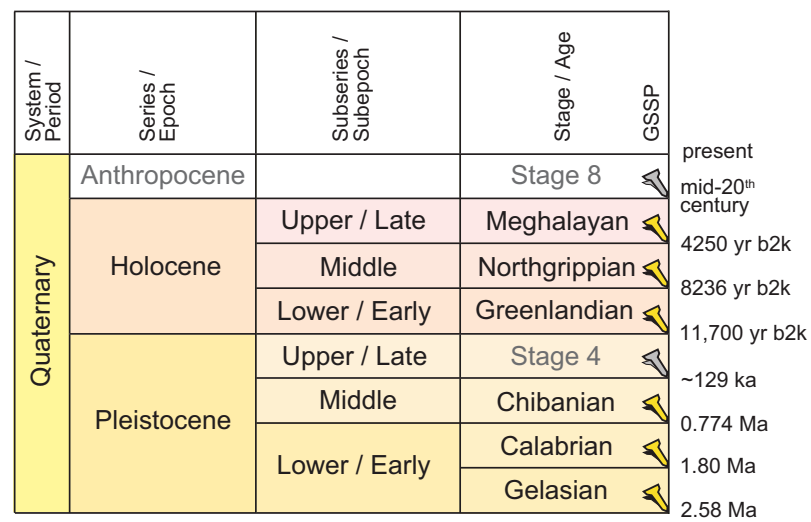

Figure 1. Formal chronostratigraphic subdivision of the Quaternary System/Period showing: a) the present IUGS-ratified scheme (Head et al., 2021), and b) the Anthropocene included according to the current preferences of the Anthropocene Working Group. Black type and yellow golden-spike symbols indicate ratified names and Global boundary Stratotype Sections and Points (GSSPs); grey type and grey goldenspike symbols indicate names not yet approved (Stage 4 and Stage 8 are placeholders) and GSSPs in progress. The abbreviation yr b2k=years before $2000 \mathrm{CE}$.

changes (Steffen et al., 2015). It represents both a range of overwhelming human impacts from the mid- $20^{\text {th }}$ century onwards and the Earth System responses to them. The Great Acceleration dataset and its analysis, having been published by Steffen et al. (2004, 2007), was then extended by Steffen et al. (2015; see also Broadgate et al., 2014 for the online dataset).

Human global energy consumption, economic productivity, and population growth have recently been analysed for the past 12,000 years (Syvitski et al., 2020). All were found to be highly correlated and show significant increases in growth along with other key environmental indicators at around $1950 \mathrm{CE}$ (Fig. 2). In particular, anthropogenic $\mathrm{CO}_{2}$ emission rates, upstream sequestration of sediment, the number of synthetic mineral-like compounds, concrete and plastics production, rates of population decline within species and translocation of species, declines in river runoff, accelerated sea-level rise, and increased coastal hypoxia all show order-of-magnitude increases after $\sim 1950$ CE (Syvitski et al., 2020). These analyses independently support the critical role of the Great Acceleration in conceptualizing the Anthropocene. The Great Acceleration represents a significant upward deflection in the Earth System trajectory, causing an abrupt departure from the envelope of variability that characterises the Holocene from its inception 11,700 years b2k through to the mid- $20^{\text {th }}$ century.

Against this significant body of analysis, Nielsen (2018a, b, and 2021a) mathematically analysed the Great Acceleration dataset of Steffen et al. (2015; also Broadgate et al., 2014) and combined these data with an earlier analysis (Nielsen, 2017) of human population and economic growth. Nielsen asserted that the growth rates of most of the datasets fit hyperbolic trajectories up to around 1960 or later, at which point they depart from that historical trend into periods of decreasing growth rates, leading to his introduction of the term 'Great Deceleration'. He concluded that the Great Acceleration data cannot be used to support a beginning for the Anthropocene, and indeed with no sudden intensification of growth there is no evidence to justify a new geological epoch (Nielsen, 2021a). Nielsen (2021b) drew a similar conclusion from his analysis of the data provided in Syvitski et al. (2020).
The purpose of this article is to place the Great Acceleration in its historical and present context, to clarify and reaffirm the significance of the Great Acceleration for the Anthropocene both in terms of timing of inception and magnitude of growth, and to correct fundamental misrepresentations (Nielsen, 2018a, b, and 2021a, b). Finally, we emphasize the geological significance of the Great Acceleration and summarize the case for a formal chronostratigraphic Anthropocene at the rank of series/epoch.

\section{The Great Acceleration}

What came to be known as the Great Acceleration graphs originated in the IGBP (International Geosphere-Biosphere Programme) synthesis project, led by one of us (WS). They were first published in the 2004 book Global Change and the Earth System: A Planet Under Pressure (Figs. 3.66 and 3.67 in Steffen et al., 2004). The graphs show (i) the very large increases in magnitude of the human drivers of global change, with the most rapid changes occurring from around 1950 onwards, and (ii) their impacts on the structure and functioning of the Earth System, leading many environmental signals to show pronounced changes following the mid- $20^{\text {th }}$ century. They play a central role as the fundamental Earth System evidence for a steep trajectory of the system away from Holocene conditions beginning around the mid- $20^{\text {th }}$ century.

The term 'Great Acceleration' was first coined in a Dahlem Workshop, held in Berlin, Germany, 12-17 th June, 2005, a year after the graphs were published in the IGBP synthesis volume. It was the $96^{\text {th }}$ workshop in the Dahlem series and had the title Integrated History and future Of People on Earth (IHOPE). The term emerged during a wide-ranging discussion of human-driven changes to the global environment through the $20^{\text {th }}$ century, the magnitude and rate of these changes, and their underlying potential human driving forces, among a mixed group of social scientists, natural scientists and humanities scholars convened and chaired by W. Steffen (Hibbard et al., 2007). 
a) Global energy consumption

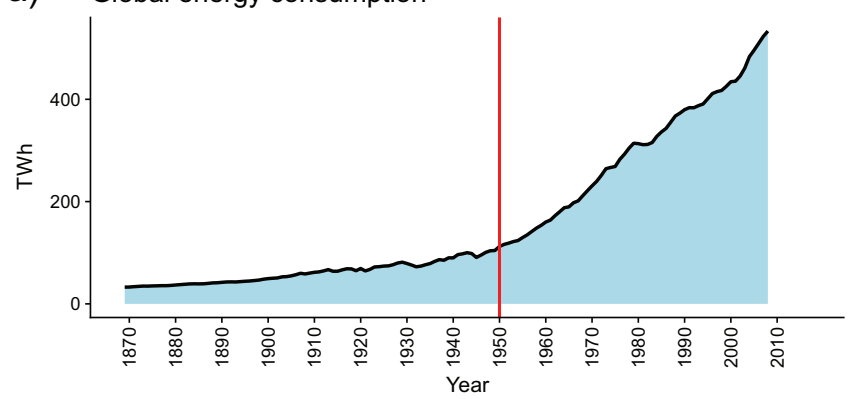

C) Global GDP per capita (2011 US\$)

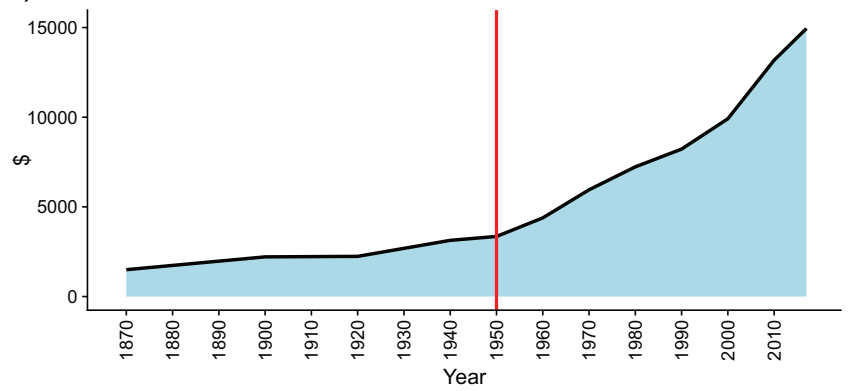

e) Global population

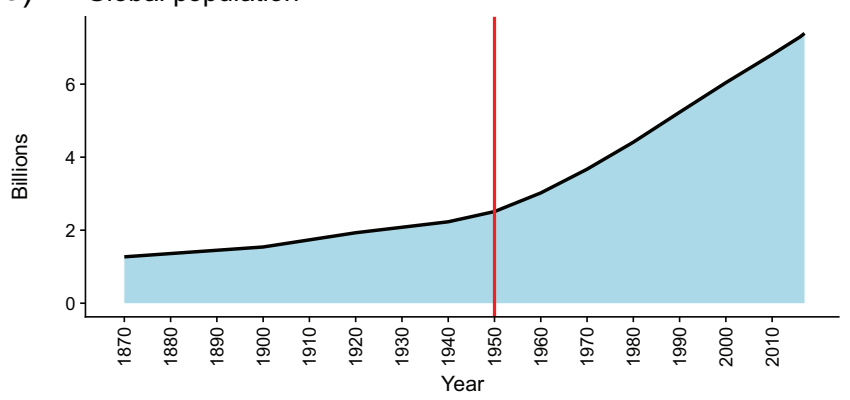

b) Annual growth rate of energy consumption

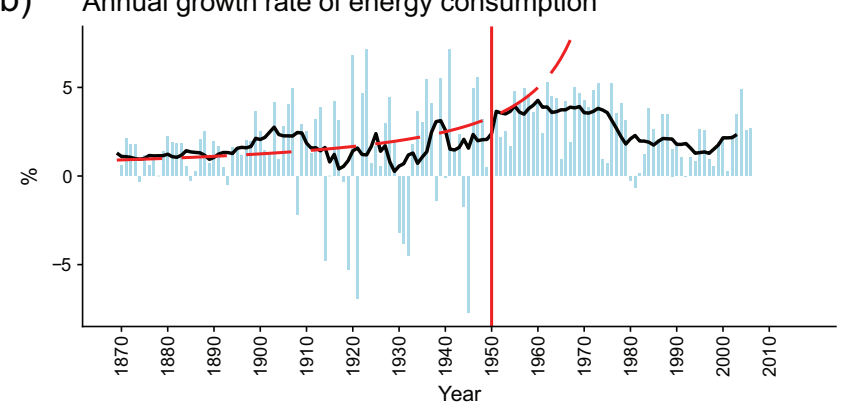

d) Annual growth rate of GDP per capita

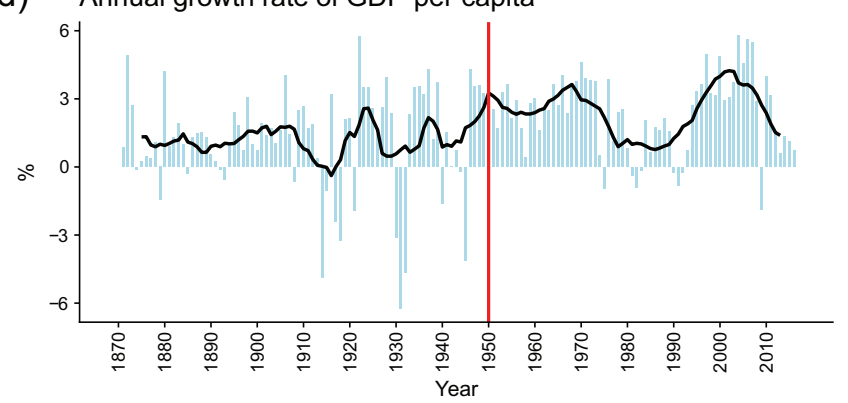

f)

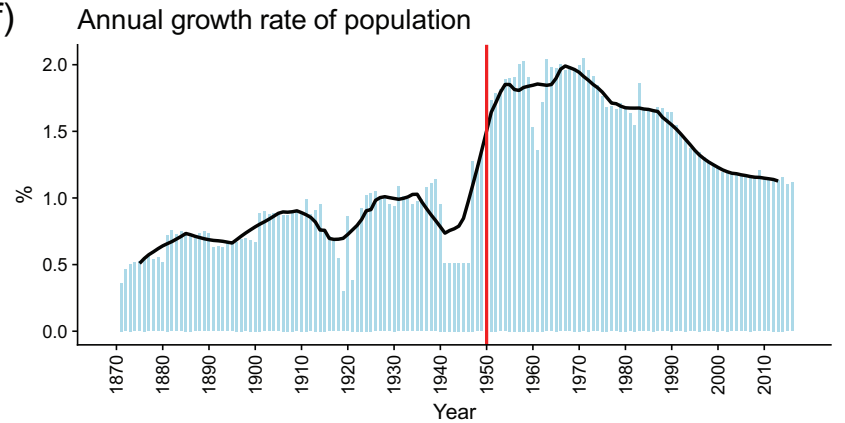

Figure 2. Major drivers of the Great Acceleration. a, b) Global human energy consumption, where the red dashed line in (b) is the model Nielsen (2018a, b, 2021a) proposed as being relevant up to $\sim 1950$. Note that important shorter-term variations in the rate of change are not well represented by simple mathematical models. $c$, d) global productivity (GDP). e, f) Global population. All three drivers show significantly increased rates at around 1950 and sustained positive (above zero) growth thereafter. The black line in b, d, and f represents a 10-year running average. Data sources: Maddison project database (2020) for population and GDP, and Steffen et al. (2015) for global human energy consumption.

The parallel between, on the one hand, the interlocked set of transitions in the $18^{\text {th }}$ and $19^{\text {th }}$ centuries among methods of economic production, social behavior, politics and law observed by Polanyi (1944) and, on the other hand, the interlocked trajectories of the Earth System and socio-political-economic system as presented by Steffen led historian J.R. McNeill to suggest the term 'The Great Acceleration' in homage to Polanyi (see also McNeill and Engelke, 2014).

The Dahlem Workshop proceedings were published in 2007 (Costanza et al., 2007). The first published use of the term Great Acceleration in this sense (based on data from the Millennium Ecosystem Assessment, the Intergovernmental Panel on Climate Change [IPCC] and other sources) appears in Chapter 18 of these proceedings after a discussion of many changes in the global environment: "The trends in carbon dioxide $\left(\mathrm{CO}_{2}\right)$ emissions and associated temperature changes also suggest a rapid acceleration of human impacts on the atmosphere over the last 50 years. These and many other changes demonstrate a distinct increase in the rates of change in many human-environment interactions as a result of amplified human impact on the environment after World War II - a period that we term the 'Great Acceleration'" (Hibbard et al., 2007, p. 342). Steffen et al. (2007), in a paper that arose from the same workshop, also used the term and concept 'The Great Acceleration' in this same sense.

It was nonetheless clear from the discussion leading to the term 'Great Acceleration', and its utilization in publications, that the term was not intended for use in a precise mathematical sense but rather metaphorically to describe great changes in both Earth System indicators and related drivers in the socio-political-economic system post1950. However, we acknowledge that 'acceleration' is open to misinterpretation as a mathematical construct or indeed in other ways, and that 'rapid increase' would be more descriptive (Nielsen, 2021b suppl. p. 7), but the term is now entrenched in the literature and there is no obvious replacement. 


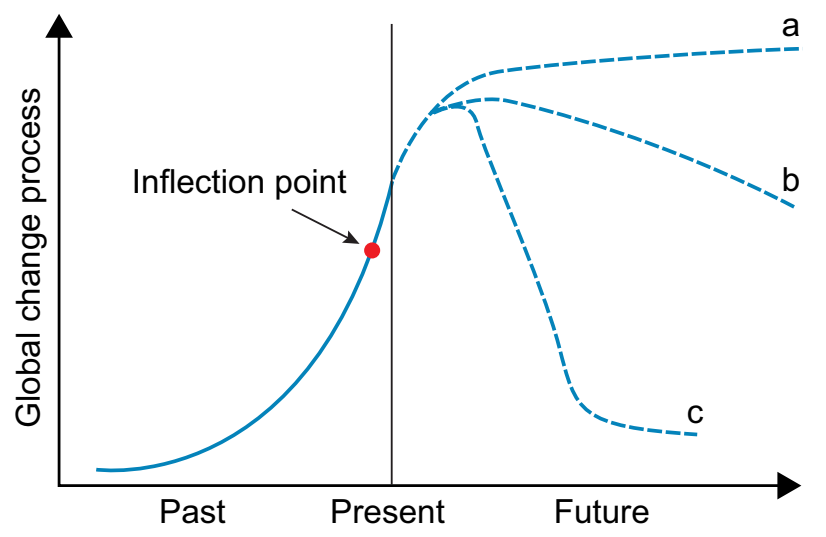

Figure 3. Three trajectories, stabilisation (a), collapse (c), and an intermediate trajectory (b), proposed by Steffen et al. (2004, fig. 3.69) to bracket the range of possible futures. The inflection point indicates when the rate of change goes from increasing, i.e., changing faster and faster, to decreasing, changing more slowly.

\section{Revisiting the Great Acceleration Data}

Even before the Great Acceleration data were assembled in the early 2000s, Earth System scientists anticipated that a steady rise in human pressure from around 1780 would support Paul Crutzen's suggestion that the Anthropocene started in the latter part of the $18^{\text {th }}$ century with the beginning of the Industrial Revolution in England (Crutzen and Stoermer, 2000). An approximately linear growth would then reflect a constant rate of change for each of the parameters over this time. The discovery that the real data showed a slow rise through the $19^{\text {th }}$ and early $20^{\text {th }}$ centuries followed by a significant increase in the rate of change around the mid- $20^{\text {th }}$ century was therefore not expected by the Earth System community, even though historians were less surprised by the rapid increase in human activity and its impacts from the mid-20 $0^{\text {th }}$ century onwards (e.g., McNeill, 2000).

The revealed pattern of a long and slow rise followed by what appears to be a sudden increase is characteristic of hyperbolic growth. Nielsen emphasized this and concluded that because the growth pattern is smooth, there are no sudden increases in growth rates that can be used to support the beginning of the Anthropocene. However, whether a hyperbolic trend is the best fit for the Great Acceleration data up to around 1950 or not has limited relevance for the Great Acceleration and the Anthropocene for several reasons.

It obscures the large short-term variations present in the empirical data, as can be seen in a plot of annual change in human energy consumption (Fig. 2b) in which Nielsen's proposed model is included. Analysing the Great Acceleration curves as if they represent a simple force growing progressively through time fails to account for the complex array of socio-economic drivers evolving over many centuries. This multifaceted history has been examined through a large body of literature including books entirely devoted to the social dynamics of $20^{\text {th }}$ century environmental change (e.g., McNeill, 2000; McNeill and Engelke, 2014). In the context of the Anthropocene, it is not important whether the high rates of change following 1950 were reached through gradually increasing growth rates as suggested by
Nielsen, or if the increase was sudden. It remains that human societies experienced an unprecedented and exceptionally fast period of growth in the decades following 1950. It misleads to label this time of sustained fast growth a 'deceleration' simply because relative growth rates did not continue to increase further.

Intervals of rapid growth should be time-limited, but Nielsen (2018a, b, and 2021a) apparently considered that any rapid growth used to support the Anthropocene should extend from the mid- $20^{\text {th }}$ century to the present day, rather than being a short-lived, immediately post-World War II event. In fact, many of his results show continuation of the proposed historical trajectory through the 1950s, and examples of deceleration tended to be towards the later decades of the $20^{\text {th }}$ century (see table 1 of Nielsen, 2021a) which could be consistent with a mid- $20^{\text {th }}$ century rapid increase in growth. The notion that rapid growth would be a short-lived, albeit transformational, event in the Great Acceleration graphs was already recognised in the original documentation in the IGBP synthesis book (Steffen et al., 2004). Nielsen (2018a, b, and 2021a) cited the IGBP book but did not refer to the possible future trajectories clearly outlined within it (Figs. 3.66 and 3.67 on pages 132-133, and Fig. 3.69 of Steffen et al., 2004).

The stylized graph in the IGBP book (Fig. 3) was intended, as with the Great Acceleration graphs, only to serve as a visual representation of the large magnitude of changes occurring in the Earth System, and of the fact that their human drivers could not continue indefinitely. That is, any rapid acceleration must necessarily be short-lived: it was suggested to occur only during a short interval around the mid- $20^{\text {th }}$ century and in the few decades thereafter. In fact, trajectories $a$ and $b$ of Fig. 3 are logistic curves in which there is an inflection representing the point at which the growth rate reaches its maximum (Smil, 2019). In Nielsen (2021a), the inflection point is synonymous with 'deceleration'. The change in growth rates must therefore by definition be highest in the 1950s and 1960s just prior to the 'decelerations', supporting the initial interpretations of the Great Acceleration.

While the relative growth of many indicators slowed in the 1970s (e.g., Fig. 2b, d and f), they crucially remain positive, and extremely rapid compared to earlier centuries, with the consequence being that the magnitudes, and associated pressures exerted by humanity on critical Earth System processes, have continued to increase. In absolute terms, these pressures and their impacts are increasing faster today than at any other time in history (IPCC, 2021). One manifestation of this is seen in the continued rapid accumulation of $\mathrm{CO}_{2}$ in the atmosphere (Fig. 4).

The resulting increases in magnitude are what give the Great Acceleration its enormous impact on the Earth System. The original Great Acceleration curves (Steffen et al., 2004, 2015) were simple plots showing changes in magnitude over time, and this depiction remains sufficient to identify a rapid and unmistakable change since 1950 . Nielsen underestimated this change in scale: "Human impacts and activities are now strong but it is questionable whether they are strong enough to cause a transition to a new geological epoch, particularly because, in general, they were becoming weaker from the 1950s or even earlier" (Nielsen, 2021a, p. 6). We emphasize that the impacts and activities of humans have not become weaker simply because they grew more slowly.

Human pressure on the Earth System grew significantly from 1950 to 2019. For example, the amount of cement produced per year has 


\section{Change in atmospheric $\mathrm{CO}_{2}$ concentration}

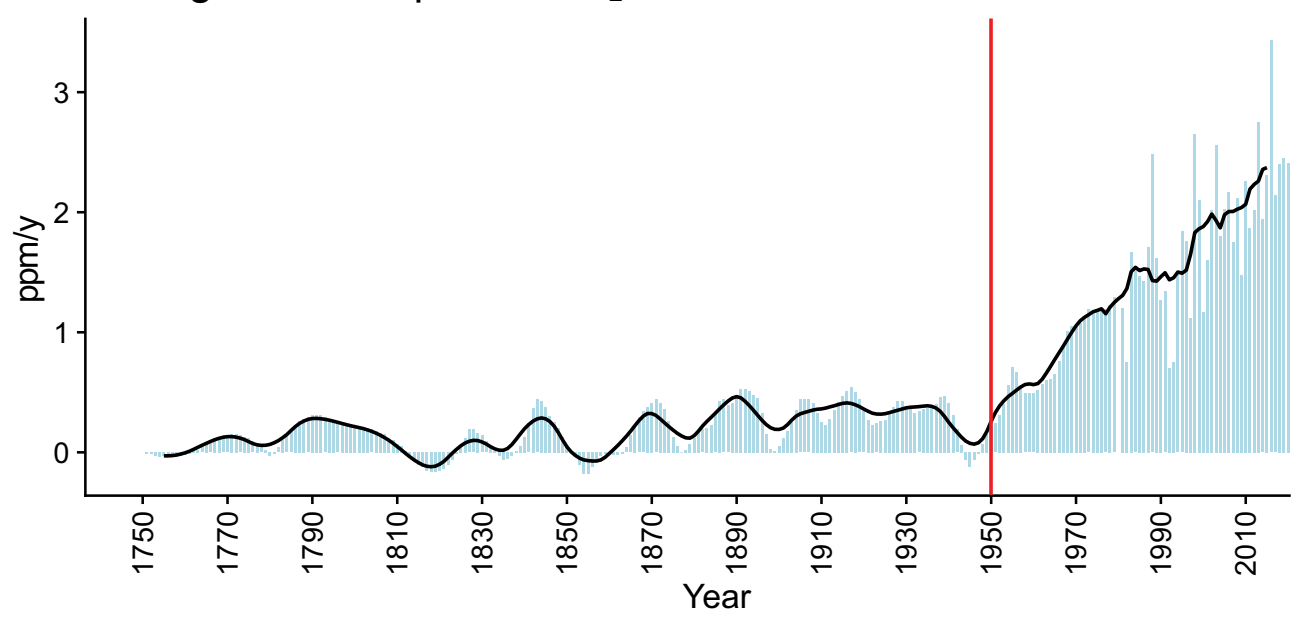

Figure 4. Change in atmospheric $\mathrm{CO}_{2}$ concentration over time. The black line represents a 10-year running average. $\mathrm{CO}_{2}$ represents a major Earth System response to the drivers of the Great Acceleration. This provides a clear illustration that concentrations have been rising at increasing rates since 1950. Data sources: Syvitski et al. (2020) up to 1980, NOAA Global Monitoring Laboratory (2021) for $1980-2020$.

Table 1. The Great Acceleration reflected in the exceptional increase in magnitude of key environmental parameters from 1950 to 2015 (see Syvitski et al., 2020 for primary data and sources)

\begin{tabular}{lcccc}
\hline \hline Indicator & 1900 & 1950 & 2015 & Relative increase since 1950 (\%) \\
\hline Population $\left(\times 10^{6}\right)$ & 1643 & 2499 & 7349 & 194 \\
Global energy consumption (EJ/y) & 41 & 100 & 514 & 414 \\
Global GDP (billions 1990 Int'l \$/y) & 1116 & 4656 & 73,902 & 1487 \\
Global reservoir capacity $\left(\mathrm{km}^{3}\right)$ & 19 & 705 & 15,534 & 2103 \\
Number of dams & 1587 & 7361 & 50,346 & 584 \\
Plastic production (Mt/y) & 0 & 2 & 381 & 18,950 \\
Cement production $(\mathrm{Mt} / \mathrm{y})$ & 5 & 130 & 4180 & 3115 \\
$\mathrm{NH}_{3}$ production $(\mathrm{Mt} / \mathrm{y})$ & 0 & 2 & 175 & 8650 \\
Copper production $(\mathrm{Mt} / \mathrm{y})$ & 0.50 & 2.38 & 19.10 & 703 \\
Iron and steel production $(\mathrm{Mt} / \mathrm{y})$ & 35 & 134 & 1160 & 765 \\
Aluminium production $(\mathrm{Mt} / \mathrm{y})$ & 0 & 2 & 58 & 2800
\end{tabular}

increased 32-fold between 1950 and 2015, from $130 \mathrm{Mt}$ in 1,950 to 4,180 Mt in 2015 (Syvitski et al., 2020; Table 1). This enormous increase in magnitude means that even though global cement production rates have not increased since 2015 (Fig. 5), the amount of cement used, and the associated impacts on the Earth System, were higher in the last decade alone (2010-2019) than during the entire $20^{\text {th }}$ century. Cement production is of particular significance both to the Great Acceleration and to the Anthropocene for two reasons. Firstly, it is a significant contributor to atmospheric $\mathrm{CO}_{2}$ which is released through the calcination process used in its manufacture $\left(\mathrm{CaCO}_{3}\right.$ [limestone]+ heat $\rightarrow \mathrm{CaO}$ [lime] $+\mathrm{CO}_{2}$ ) together with $\mathrm{CO}_{2}$ produced from the energy required to heat limestone. Secondly, most cement is used for concrete production, with approximately $15 \%$ of average concrete mass consisting of cement (Waters and Zalasiewicz, 2018). This requires the excavation of much larger volumes of aggregate (sand, gravel, etc.) which contributes proportionally to changes in the global sediment budget. Concrete also contains components that mark modern cement as a new rock-like material, linking it directly with the geological expression of the Anthropocene (Waters and Zalasiewicz, 2018).
Unsurprisingly, the production of cement (Fig. 5) is closely linked with the post-World War II expansion of the built environment and with other key environmental parameters. Table 1 shows the striking increase in scale for many of these parameters.

Similarly, an analysis of Earth's sediment cycle, which is the very foundation of stratigraphy, reveals the overwhelming dominance of modern industrial activity (Syvitski et al., in press). The global sediment flux presently exceeds $300 \mathrm{Gt} / \mathrm{y}$, of which $>96 \%$ results from human activity. This is the mass equivalent of each human moving $\sim 37.5$ metric tons per year. It compares with estimated values of around $73 \mathrm{Gt} / \mathrm{y}$ for $\sim 1950,11 \mathrm{Gt} / \mathrm{y}$ for the post-glacial Holocene, $22 \mathrm{Gt} / \mathrm{y}$ for the deglacial Holocene, $11.4 \mathrm{Gt} / \mathrm{y}$ for the Quaternary, and $5 \mathrm{Gt} / \mathrm{y}$ for the Phanerozoic Eon. These estimates imply that the sediment flux is presently at a rate rarely if ever attained in 541 million years of Earth history (Syvitski et al., in press).

Nielsen's strong focus on relative changes in Great Acceleration data (Nielsen, 2018a, b, and 2021a) fails to address the significance of magnitude, which has extended aspects of the Earth System far beyond the natural variability of the Holocene. 


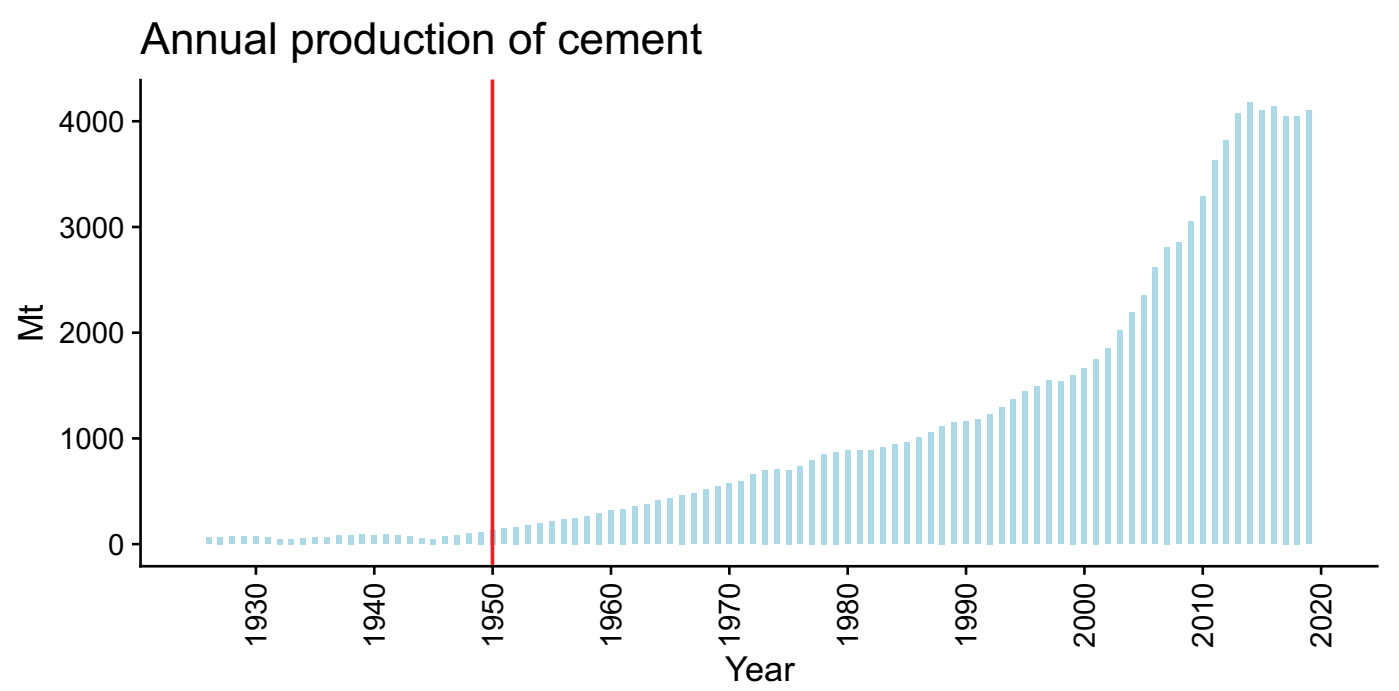

Figure 5. Annual production of cement, showing an initial rise $\sim 1950$. Crucially, the amount of cement produced per year has increased 31 times between 1950 and 2015. Data sources: Syvitski et al. (2020) up to 2014, International Energy Agency (2021) for 2015 -2019.

The relationship between the magnitude of the drivers (and the rate at which they change) and the responses of the Earth System to these drivers is complex, has been examined in a large body of literature, lies at the heart of contemporary Earth System science, and is not amenable to simple mathematical analysis. Absolute rates of change in the climate system (e.g., $\mathrm{CO}_{2}$ and temperature rise; Lear et al., 2020) and in the biosphere (IPBES, 2019) are generally highest today. When viewed in terms of resource utilization and corresponding outflows of wastes and emissions, the Earth System has undergone significant upturns in metabolism around 1950 and again from the beginning of the $21^{\text {st }}$ century (Krausmann et al., 2018). All these features indicate that the mid- $20^{\text {th }}$ century was an absolutely critical period when the Earth System began its clear departure from the Holocene envelope of variability at increasing rates. This is how Earth System science defines the time at which the Anthropocene begins, and it aligns with an extensive array of stratigraphic signals (Waters et al., 2018).

\section{Non-uniform Responses to the Great Acceleration}

The Great Acceleration around 1950 is clearly marked by upturns in population growth, GDP, energy consumption (Fig. 2) and many other critical indicators, as discussed above. Some indicators, however, show declines in growth rate after 1950 owing to increasingly limited resources, and others have their upturns delayed through feedbacks in the Earth System. This range of responses was anticipated (Fig. 3) and reflects the complexity of the Great Acceleration concept as a planetary phenomenon.

The global total number of existing large dams (Table 1) and global marine fish capture (Fig. 6) both show declines in growth rate towards the end of the $20^{\text {th }}$ century. This should not be interpreted as reflecting declines in human impact. In the case of large dams (minimum $15 \mathrm{~m}$ height above foundation), the number built has been limited by the finite number of large rivers that can be dammed, and that limit is

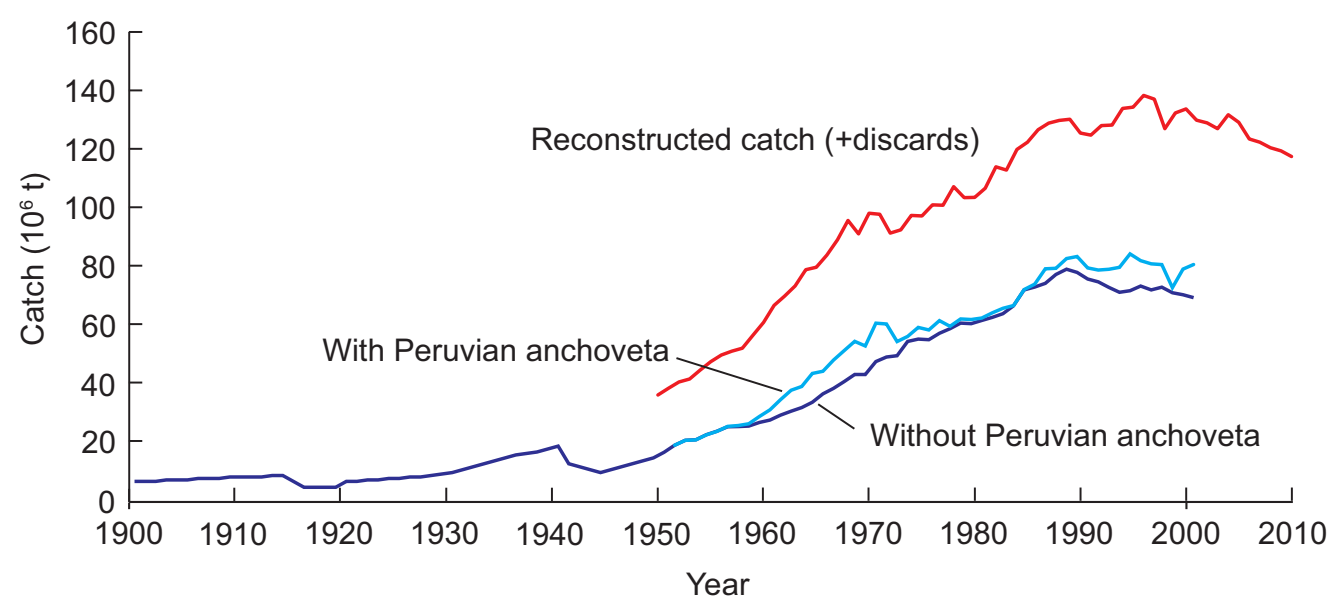

Figure 6. Global marine fish catch figures based on Pauly et al. (2003, light and dark blue lines) and Pauly and Zeller (2016, red line) which includes discarded bycatch. Note a clear rise in the 1950s and 1960s, a reduced rate of growth in the 1970s to 1990s, and a decline from around the year 2000. The increased rate of growth in the 1950s and 1960s cannot be sustained, despite improved technical innovations, owing to the depletion of fish stocks. 
being approached (Steffen et al., 2015). Regarding global marine fish capture, an actual decline in numbers is recorded as global fish stocks become depleted. Simply put, an exponential increase of fish capture will inevitably lead to population crash (Pauly et al., 2003; Pauly and Zeller, 2016; Sumaila et al., 2016). Overfishing will also potentially have left a biostratigraphic signature in the form of assemblage changes and reduced diversity both in the open oceans (Thrush et al., 2016) and coral reef systems (Bellwood et al., 2004; Hughes et al., 2017). Furthermore, bottom trawling modifies the benthos and destroys sedimentary structures, the combined actions of which will be apparent in the Anthropocene sedimentary record (Hiddink et al., 2006). Given that bottom trawling is prevalent on all continental shelves, yields about a quarter of the world's wild seafood (Mazor et al., 2021 and references therein), and is now extending down the continental slope, this stratigraphic signal is probably global in extent.

Other indicators have upturns that are delayed by complex feedback loops. Global temperature, for example, does not precisely follow $\mathrm{CO}_{2}$ as its most rapid rise began around 1970 (Fig. 7). One explanation is that the industrial processes responsible for the post-World War II rises in the Great Acceleration graphs were based partly on the use of production lines of the kind that formerly made war materiel. Diverted to produce consumer goods, these production-lines and others rapidly assembled using the same techniques to produce consumer goods were crude and dirty, loading the air with aerosols that reflected solar energy. An increased demand for electricity also led to a rise in aerosols owing to an increase in coal use and the use of fuel-oil to generate this electricity. Aerosol production was a factor in slowing the rise in global temperature, especially between 1950 and 1980, temporarily disconnecting it from rising $\mathrm{CO}_{2}$ levels (Smith et al., 2016; Haustein et al., 2017, 2019; Qin et al., 2020). The anthropogenic global warming signal emerged in the mid-1970s only when clean air regulations came into force more or less globally (Haustein et al., 2019). A second explanation is that natural oscillations in the oceanic transfer of heat through the North Atlantic by the Atlantic Meridional Ocean Circulation led to heat storage in the ocean in the $1950 \mathrm{~s}$, and heat release to the atmosphere in the 1980s and beyond (Chen and Tung, 2018). These natural fluctuations in surface temperature reflect the internal dynamics of the Earth System and are largely independent of the effects of $\mathrm{CO}_{2}$. These effects are superimposed upon the curve of rising temperature attributable to rising greenhouse gases, which also include water vapour derived from increasing oceanic evaporation in a warming world. All these effects led to a step-wise increase in temperatures with plateaus of lower increase followed by acceleration, such as the 1976 rise followed by a slower rise between 1998 and 2012 (Medhaug et al., 2017; Cheng et al., 2021). Nevertheless, paleoclimate data have quantified the emergence of anthropogenic warming in all tropical oceans and the Arctic between 1948 and 1962, well before the emergence of warming on many continental areas (Abram et al., 2016). The Earth is currently in a new accelerated phase of warming (Johnson and Lyman, 2020). Thus, slow oceanic and rapid atmospheric feedbacks played a role in climatological time series, either averaging or delaying some of the changes occurring around 195060 . But viewed over the 150 -year record, there will be an increase from a time reasonably close to 1950-60. The most striking signal of ongoing anthropogenic warming is the storage of heat in the global oceans (IPCC, 2021). Approximately $90 \%$ of the heat from global warming resides in the oceans. Ocean heat content started to rise more steeply just before 1950 and since then has penetrated to depths of at least 2,000 m globally (Cheng et al., 2017; Abram et al., 2019). At the same time, ocean salinity has revealed an amplification in the global water cycle over the past 60 years. The fresher parts of the ocean are becoming fresher, while the salty parts are becoming saltier, due to a combination of ice melt in polar regions and evaporation in tropical regions (Cheng et al., 2020; Gould and Cunningham, 2021). 
These oceanic impacts of warming during the Anthropocene are affecting ocean currents through the key role salinity plays. Changing patterns of heat transport in the Gulf Stream are already causing a slowdown in the Atlantic Meridional Ocean Circulation that until recently has warmed the North Atlantic between Newfoundland and Ireland, where cooling now occurs (Caesar et al., 2021).

Atmospheric $\mathrm{CO}_{2}$ represents a major Earth System response to the drivers of the Great Acceleration, and concentrations have been rising at increasing rates since around 1950 (Fig. 4). Even if anthropogenic $\mathrm{CO}_{2}$ emissions decline in the future, atmospheric $\mathrm{CO}_{2}$ concentrations will remain high through equilibrium with the $\mathrm{CO}_{2}$ concentration in the surface ocean. This is because a reduction in human emissions will lead to an increase of $\mathrm{CO}_{2}$ emissions from the ocean to balance that loss. "Equilibration with the ocean will absorb most of $\left[\right.$ the $\left.\mathrm{CO}_{2}\right]$ on a timescale of 2 to 20 centuries. Even if this equilibration were allowed to run to completion, a substantial fraction of the $\mathrm{CO}_{2}, 20-40 \%$, would remain in the atmosphere awaiting slower chemical reactions with $\mathrm{CaCO}_{3}$ and igneous rocks. The remaining $\mathrm{CO}_{2}$ is abundant enough to continue to have a substantial impact on climate for thousands of years." (Archer et al., 2009, p. 131). Global sea-level rise is similarly locked in for centuries or millennia to come, even with emission reductions, and a recent modelling simulation predicts global mean sea level to rise continuously over the next 10,000 years under all scenarios considered (Van Breedam et al., 2020). Erosional and depositional processes associated with this global sea-level rise will therefore continue to operate on a significant geological time scale.

\section{Implications of the Great Acceleration for an Anthropocene Epoch}

The Great Acceleration is a truly interdisciplinary concept and in this context is being examined for its stratigraphic usefulness by the AWG (see below). We have shown that massive increases in the growth of global socio-economic indicators and Earth System trends that represent the Great Acceleration are a real and striking phenomenon, with major geological consequences.

The Great Acceleration provides the narrative for a new interval of geologic time starting in the mid- $20^{\text {th }}$ century, while also establishing the framework enabling the scale of critical Earth System drivers to be placed in context. Among the most potent of these drivers are atmospheric $\mathrm{CO}_{2}$ and methane (Fig. 8).

The global average atmospheric $\mathrm{CO}_{2}$ concentration in 2019 was $409.8 \pm 0.1 \mathrm{ppm}$ (Lindsey, 2020), more than $100 \mathrm{ppm}$ higher than the highest concentration prior to the $20^{\text {th }}$ century during the past 800,000 years of Antarctic ice core records. Modeling studies indeed suggest that concentrations are now higher than they have ever been during the past three million years (Willeit et al., 2019), and proxy records imply that $\mathrm{CO}_{2}$ concentrations had not attained present levels since about $14 \mathrm{Ma}$ in the Middle Miocene (Zhang et al., 2013) or perhaps even earlier (Cui et al., 2020). The rate of increase in atmospheric $\mathrm{CO}_{2}$ concentration rose sharply from the mid-20th century to the present, on average about 100 times greater than the rate of increase from the Late Pleistocene to the Early Holocene (Zalasiewicz and Waters, 2019; Lindsey, 2020).

With respect to methane, over the past 800,000 years of Antarctic ice core records, levels had never exceeded $\sim 800 \mathrm{ppb}$ (Loulergue et al., 2008) but reached $801 \mathrm{ppb}$ in 1850 , were at $1,162 \mathrm{ppb}$ in 1950 , and 1,858 ppb in 2018 (Our World in Data, 2020; Fig. 8). These increases in $\mathrm{CO}_{2}$ and methane do not represent anthropogenic emissions exclusively as they reflect a planetary response to a wide range of human impacts. The global human population responsible for these changes has risen from 1,643 million in 1900 , to 2,499 million in 1950, and 7,349 million in 2015 (Syvitski et al., 2020; Table 1).

The analysis of changing socio-economic trends is not strictly relevant to the definition of the Anthropocene as a chronostratigraphic unit, but it provides the narrative framework for the Anthropocene concept, in that socio-economic drivers, from the mid- $20^{\text {th }}$ century onwards, have significantly perturbed Earth System signals beyond the envelope of Holocene norms, just as asteroid impact-driven processes dramatically perturbed the Earth System from a Cretaceous to a Paleogene state 66 million years ago.

While the appropriate mathematical analysis of Earth System and socio-economic trends might yield useful information about underlying process-based causes, geological signals are rarely suited to the same scrutiny because they carry uncertainties in age modeling, diagenetic effects, taphonomic processes and so on. Instead, a more practical approach is used to identify marked upturns or downturns in a signal without considering its fit to a hyperbolic, exponential, or any other hypothetical curve.

The subdivision of the Holocene (Fig. 9) exemplifies this approach. The base of the Holocene Series (and Lower Holocene Subseries and Greenlandian Stage) is defined by a GSSP in the Greenland NGRIP2 ice core (Walker et al., 2009, 2018, and 2019). The GSSP is marked by an 'abrupt decline' in deuterium excess values that is clearly visible in the data plots without statistical analysis (Fig. 9a). This decline represents a rapid ( $\leq 3 \mathrm{yr}$ ) northward retreat of the oceanic polar front, signalling a major climatic shift during the more protracted warming from glacial to interglacial conditions. This northward (warming) shift of the sea-ice margin in the North Atlantic paradoxically now caused moisture precipitating over Greenland to be sourced from higher (colder) latitudes (Walker et al., 2009). The GSSP is placed near the midpoint of the steepest part of this shift in deuterium excess values. Attempting to fit this plot to a hyperbolic or exponential curve is neither realistic nor meaningful.

The base of the Northgrippian Stage (and Middle Holocene Subseries) is traceable globally via a pronounced climatic event at $8.2 \mathrm{ka}$. This event is marked by a brief shift to more negative $\delta^{18} \mathrm{O}$ values in the Greenland NGRIP1 ice core that hosts the GSSP (Fig. 9b) coincident with an abrupt cooling event. In detail, however, the GSSP aligns with a geochemical signal of volcanic activity during the $8.2 \mathrm{ka}$ climatic event, allowing precise correlation with other Greenland ice cores (Walker et al., 2018, 2019). Its position was not chosen with regard to the internal geometry of the $\delta^{18} \mathrm{O}$ shift even though this represents the primary guide for global correlation of this chosen level. The GSSP defining the base of the Meghalayan Stage (and Upper Holocene Subseries) is placed approximately midway between two abrupt successive shifts to less negative $\delta^{18} \mathrm{O}$ values in the KM-A speleothem (Fig. 9c), indicating abrupt reductions in precipitation. This 'mid-point' approach follows established practice without requiring detailed mathematical analysis of the data across this interval (Walker et al., 2018, 2019; Head, 2019). Such analysis would be pointless 


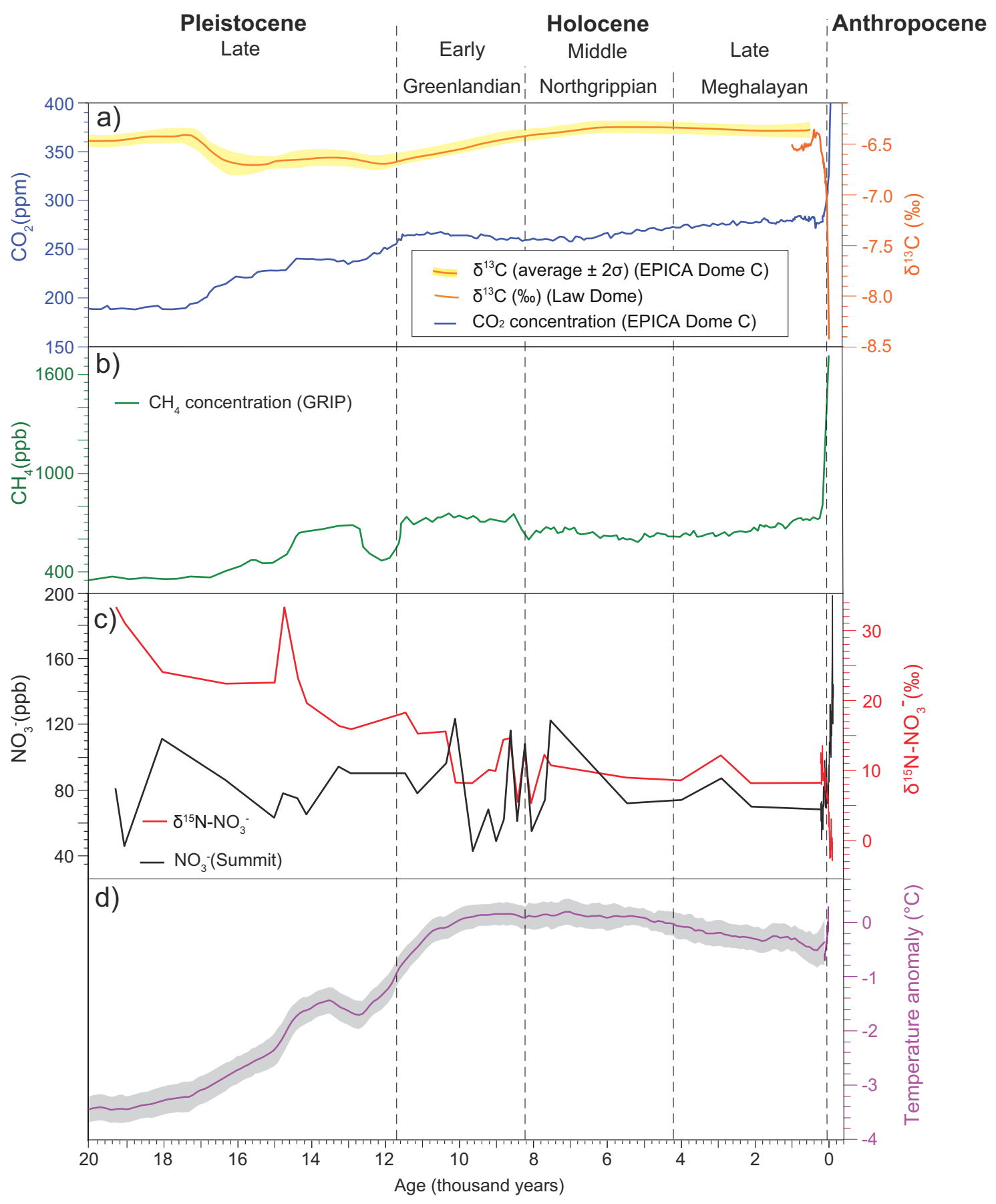

Figure 8. Key trends and drivers for the Anthropocene from the Late Pleistocene to present, based on ice core records from Greenland (Greenland Ice Core Project [GRIP], Summit) and Antarctic (European Project for Ice Coring in Antarctica [EPICA] Dome C, Law Dome) and modern instrumental data (a-c, adapted from figs. 1 and 2 respectively of Zalasiewicz et al., 2018, 2019b). d) Global temperature anomalies (mean and one standard deviation) relative to the 1980-2004 mean are adapted from Clark et al. (2016). Relative stability characterises the Holocene, and sharp deflections the Anthropocene. The start of the Anthropocene in the mid-20 ${ }^{\text {th }}$ century contrasts with the relatively gradual changes, at this scale, across the Pleistocene-Holocene boundary. Despite the global temperature rise during the Pleistocene-Holocene transition being of greater magnitude, the rate of rise over the past century of $1.25^{\circ} \mathrm{C}$ far exceeds the average of $0.05^{\circ} \mathrm{C}$ per century over the 7000 year warming during the Late Pleistocene-Early Holocene transition.

given the 'noise' within any single $\delta^{18} \mathrm{O}$ speleothem signal, and these signals may vary even within the same cave system. The precise position of this boundary was chosen to coincide with $4.2 \mathrm{ka}$ on the time scale used, which was of more practical use in this instance.

The validity of these (and all the other) formal chronostratigraphic units does not therefore depend on the mathematical testing of the stratigraphic signals used to characterise them, as the practical use of these units to Earth scientists has long been shown by their effective and systematic application in day-to-day work.

Defining any unit of the Geological Time Scale and documenting 

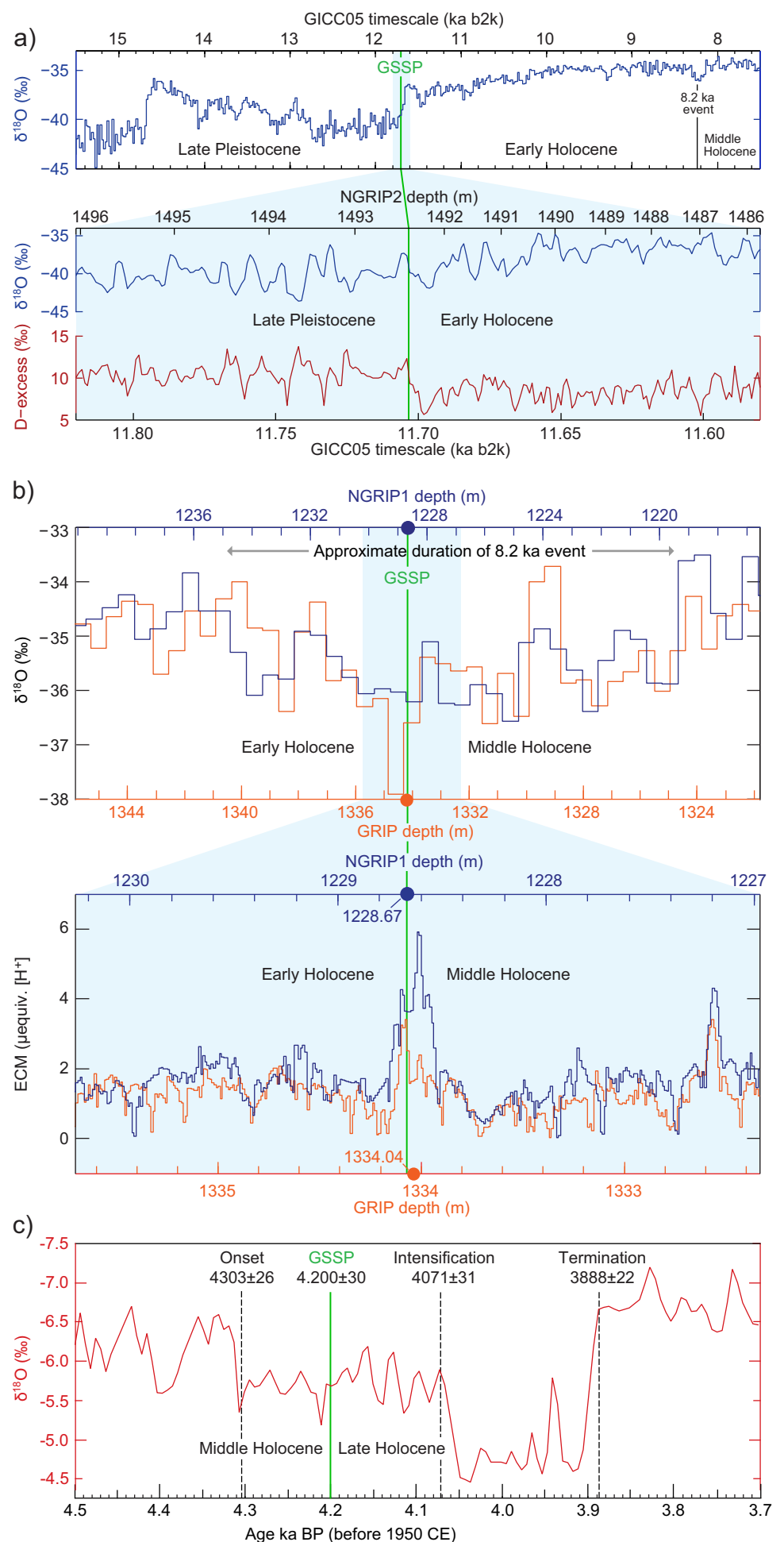

Figure 9. Chemical (climatic) indicators used to recognise and subdivide the Holocene Series/Epoch. A green line represents the position of the Global boundary Stratotype Section and Point (GSSP) in each case. a) Base Holocene Series and base Greenlandian Stage, defined by GSSP in the North Greenland Ice Core Project (NGRIP) 2 ice core at a depth of 1492.45 m, placed within an overall trend towards less negative $\delta^{18}$ O values (upper panel) and precisely at an initial abrupt decline in deuterium-excess values (lower panel). The Greenland Ice Core Chronology 2005 (GICC05) used here is expressed in years before 2000 CE (b2k). b) Base Northgrippian Stage, defined by GSSP in the NGRIP1 ice core at a depth of $1228.67 \mathrm{~m}$, placed within the ' $8.2 \mathrm{ka}$ climatic event' as expressed by more negative ${ }^{18} \mathrm{O}$ values (upper panel) and precisely at a double acidity peak reflected by electrical conductivity measurements (ECM) and representing a strong volcanic signal. c) Base Meghalayan Stage, defined by GSSP in the KM-A speleothem, Meghalaya, India at a depth of $7.45 \mathrm{~mm}$ from its unweathered distal end (Head, 2019), and placed at $4.2 \mathrm{ka}$ on the timescale used, which coincides with the approximate midpoint of a two-step shift to less negative $\delta^{18} \mathrm{O}$ values and signals a decrease in monsoon rainfall. It would not be appropriate, helpful or informative to analyse these signals, used to place the GSSPs that define the Holocene and its subdivision, by means of continuous mathematical functions. (Adapted from Walker et al., 2018, 2019; Head, 2019). 
its contents can be accomplished only using evidence from the rock record and other geological archives (Salvador, 1994; Remane et al., 1996), as noted by Nielsen (2021b). However, changes to the Earth System state often provide the underlying rationale to justify the introduction and rank of a new unit of geological time. The traditional evidence for such changes in state has been exclusively geological (e.g. paleontology revealing mass extinction events) - but historical and instrumental records must be included when available as they too represent geological time. The Great Acceleration offers not only this justification for the Anthropocene and its rank, indeed with unsurpassed detail, but it has also given rise to a multitude of signals indelibly preserved in the geological record.

\section{Ongoing Analysis of the Anthropocene as a Poten- tial Unit of the Geological Time Scale}

In 2009, the Subcommission on Quaternary Stratigraphy, a constituent body of the International Commission on Stratigraphy (ICS), established the Anthropocene Working Group (AWG) to evaluate the Anthropocene as a potential unit of the International Chronostratigraphic Chart upon which the Geological Time Scale is based. An early priority of this working group was to examine a wide range of existing geological, historical and instrumental data sets, with the purpose of determining whether the Anthropocene had appropriate expression in the geological record, when might best represent the onset of the Anthropocene, and whether the originally proposed rank of epoch/ series was justifiable. The approach, although focused on geology, was multidisciplinary, reflecting the overlap of geological and historically observed time and process in this interval with a correspondingly diverse AWG membership (Zalasiewicz et al., 2017a). The initial suggestion of a late $18^{\text {th }}$ century onset for the Anthropocene (Crutzen and Stoermer, 2000; Crutzen, 2002) was followed by Steffen et al. (2007) who subdivided the Anthropocene into three stages, linking the Great Acceleration to a 'stage 2', and with 'stage 3' being a consideration of potential future scenarios (see also Steffen et al., 2011). However, Zalasiewicz et al. (2014) provisionally used the Great Acceleration to recognise the beginning of the Anthropocene, dated at approximately 1950. This conceptual link between the Anthropocene and the Great Acceleration was affirmed by the AWG shortly thereafter (Zalasiewicz et al., 2015). Indicative voting within the AWG in 2016 confirmed support for the Anthropocene as a stratigraphically substantiated unit, and that it should be defined by a Global boundary Stratotype Section and Point (GSSP) and formalized at the rank of epoch with an inception at $\sim 1950 \mathrm{CE}$ (Zalasiewicz et al., 2017b). A binding vote by the AWG in May 2019 addressed two critical questions: should the Anthropocene be treated as a formal chronostratigraphic unit defined by a GSSP, and should the primary guide for the base of the Anthropocene be one of the stratigraphic signals around the mid- $20^{\text {th }}$ century of the Common Era (CE)? Each vote was carried decisively with 29 in favour, 4 against, no abstentions; with 34 potential voting members (one ballot not returned). Selecting a marker event of optimal correlation potential in advance of the GSSP itself follows normal stratigraphic practice (Remane et al., 1996). The Great Acceleration, with its multitudinous stratigraphic and other signals and magnitude of change, is central both in characterizing the base of the Anthropocene and in justifying its proposed series/epoch rank. If the Anthropocene as currently envisioned by the AWG, and its corresponding stage/age, are approved by the ICS and ratified by the Executive Committee of the IUGS, they will terminate the Holocene Series/Epoch and the Meghalayan Stage/Age respectively, and the Anthropocene will constitute a third series/epoch for the Quaternary System/Period (Fig. 1).

The Great Acceleration, however, does not define the chronostratigraphic base of the Anthropocene - only a GSSP can do this (Salvador, 1994; Remane et al., 1996). The geological expression of the Anthropocene is now documented (e.g., Waters et al., 2016, 2018; Zalasiewicz et al., 2019b), and 12 GSSP candidate sections are being examined for their suitability to record stratigraphic signals around the mid- $20^{\text {th }}$

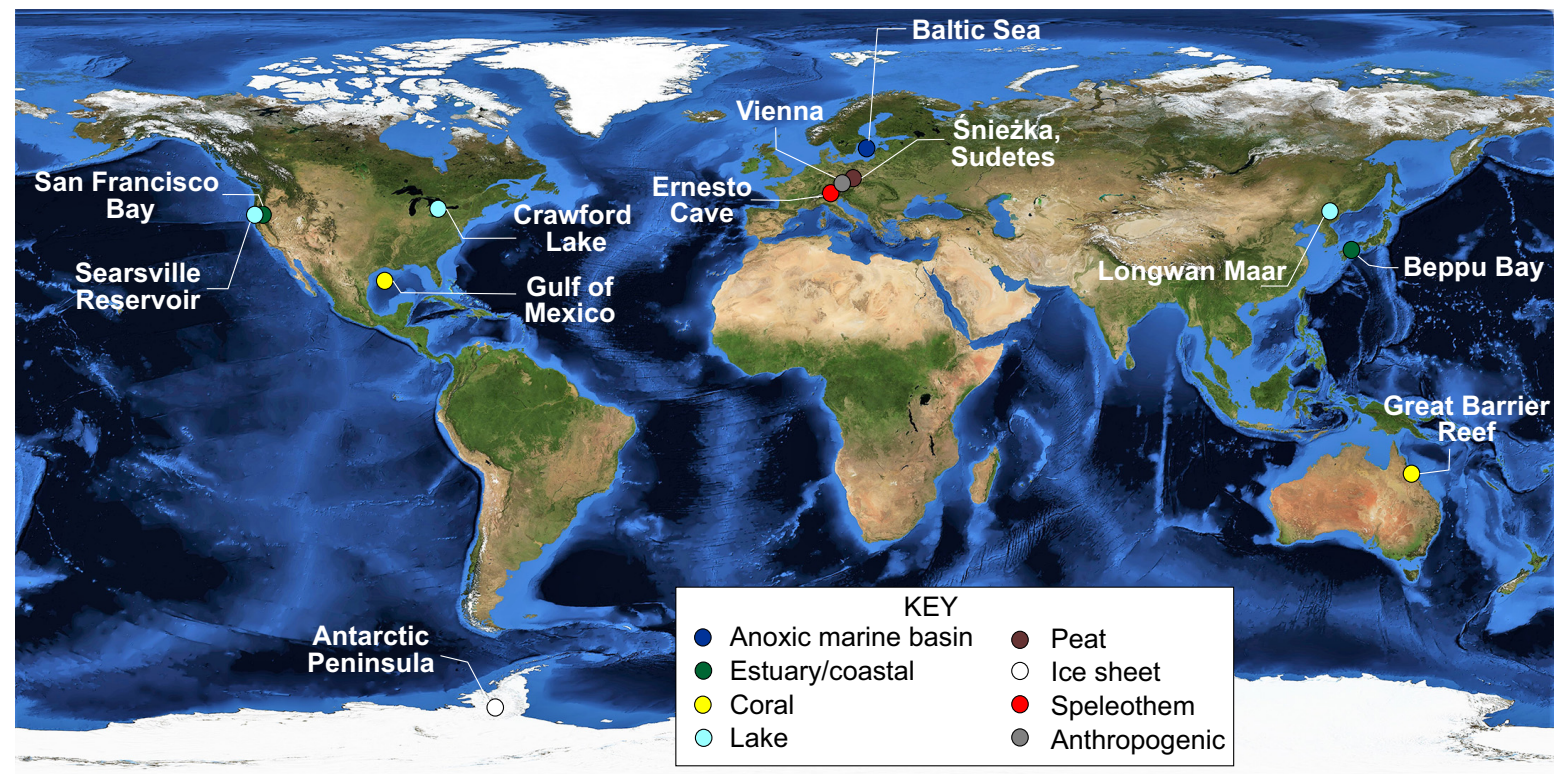

Figure 10. Location of candidate GSSP localities currently under investigation indicating the depositional environment. Satellite image: NASA Visible Earth. 


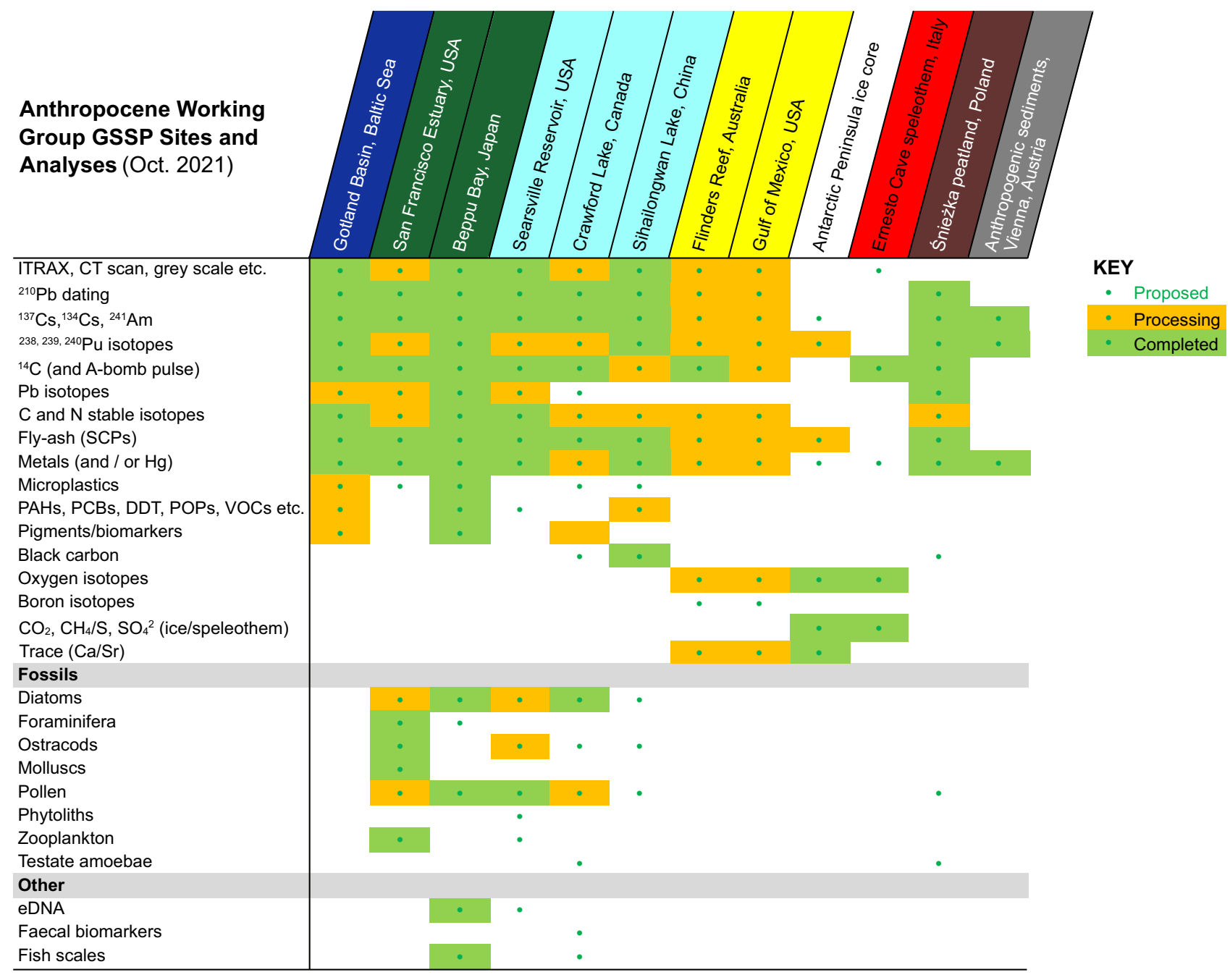

Figure 11. The range of stratigraphic markers as of 25th October 2021 being investigated at the 12 candidate GSSP sites. The following abbreviations are used: $C T=$ computed tomography, $S C P S=$ spheroidal carbonaceous particles, PAHs=polycyclic aromatic hydrocarbons, PCBs=polychlorinated biphenyls, DDT=dichlorodiphenyltrichloroethane, POPs=persistent organic pollutants, VOCs=volatile organic compounds, and eDNA=environmental deoxyribonucleic acid.

century (Figs. 10, 11). Archives being explored include an ice core from Palmer Land on the Antarctic Peninsula, lake sediments from California (USA), Ontario (Canada) and Jilin Province (China), coastal sediments from California (USA) and Kyushu Island (Japan), marine sediments from the Baltic Sea, a peat sequence from the Sudetes Mountains (Poland), corals from the Great Barrier Reef (Australia) and Gulf of Mexico (USA), a speleothem from the Trentino region (Italy) and anthropogenic deposits from Vienna (Austria). A further suggestion to use dendrochronological records by Waters et al. (2018) has not progressed to the analysis of a candidate GSSP, although Turney et al. (2018) suggested using a non-native Sitka spruce from Campbell Island, New Zealand. However, their proposal provided just one signal, carbon-14 for only a six-year duration through the peak of the bomb-spike, failing to record the onset of the signal or any proxy data characterising the Holocene-Anthropocene transition. Most sites are in borehole cores, although the Vienna site also includes a trench section, and one site is represented by a stalagmite (the Ernesto speleothem). Many of the sites show annually to sub-annually resolved laminations (Crawford and Longwan Maar lakes, Beppu Bay coastal sediments, the Gulf of Mexico and Great Barrier Reef corals, the Antarctic Peninsula ice core and the Ernesto Cave speleothem) that can be independently dated radiometrically to confirm a complete succession extending to pre-Industrial times. The Anthropocene components of the sections range from as little as $5 \mathrm{~mm}$ for the speleothem to about $34 \mathrm{~m}$ for the ice core.

Earth System trends that characterise the Great Acceleration are unsurprisingly closely aligned to the signals that are being considered within geological archives, although often only through proxies (Zalasiewicz et al., 2017c). Archives of carbon dioxide, nitrous oxide and methane concentrations predating the 1950 s can only be determined from glacial ice (Fig. 8), such as the Palmer ice core (with the exception of rare atmospheric $\mathrm{CO}_{2}$ measurements dating to the $1880 \mathrm{~s}$; Summerhayes, 2008), and are unsuitable for correlation within other geological successions. More practical for correlation across diverse environments is the analysis of trends of stable carbon and nitrogen isotopes (not discussed by Nielsen, 2021a, b; see Fig. 8a and 8c) and 
which are to be analysed across most of the candidate GSSP sites, except the ice core, speleothem and anthropogenic deposits (Fig. 11). Temperature anomaly trends of modern times are based on combined land and ocean observations, not on geological records which rely on investigating proxy signals such as stable oxygen isotopes which are to be investigated in the candidate GSSP ice core, speleothem, and corals (also with $\mathrm{Sr} / \mathrm{Ca}$ ratios in the last of these). Temperature records can also be determined from growth extension rates in dendrochronological records (Fig. 8d), although no such candidate site is currently being considered. Similarly, present ocean acidification trends are based upon direct ocean measurement, and to trace this record through geological time it is necessary to analyse the proxy signal of $\delta^{11} \mathrm{~B}$ isotopic records in foraminiferal and coral carbonates (including the two coral candidate sites), or through the effect on biotic assemblages. Changes in stratospheric ozone have no physical geological expression other than traces in polar ice; but global values for marine fish capture, global shrimp production, loss of tropical forests, and changes to global agricultural land area may be recorded in geological archives through changes in biotic marine and terrestrial assemblages (e.g., recorded for example by sardine and anchovy scale deposition rates at the Beppu Bay site in Japan) and increased erosion leading to greater sediment accumulation rates (e.g., strikingly seen in Fontanier et al., 2018).

Potential primary markers include the presently favoured nuclear fallout-derived plutonium-239 record. Its initial rise as detected in sediments appears near-isochronous and near-global in extent, as required for optimal correlation. This signal, almost exclusively anthropogenic in origin, is dated to $\sim 1952 \mathrm{CE}$ based on its presence in sediments and other geological materials and reflects its pronounced rise in production at this time (Waters et al., 2015, 2019). Plutonium is being analysed for all sites, except the speleothem GSSP candidate (Fig. 11), and can be used in conjunction with other radionuclides, including the naturally occurring carbon-14, which shows an abrupt upturn from $\sim 1955$ in response to atmospheric nuclear tests. It is nonetheless the array of stratigraphic signals associated with the Great Acceleration (Zalasiewicz et al., 2017c) that in practice would allow routine recognition of the base of the Anthropocene in many diverse natural archives and environments (Waters et al., 2018; Zalasiewicz et al., $2019 \mathrm{~b}$ ) and which to varying degrees are present at the candidate GSSP sites (Fig. 11). Such signals include the appearance of microplastics (Zalasiewicz et al., 2016; Bancone et al., 2020), upturns in abundance of fly-ash (Rose, 2015) and black carbon (Han et al., 2017), increased lead abundance and perturbed lead isotopes (Reuer and Weiss, 2002), increased abundance of persistent organic compounds such as PCBs and novel pesticides (Gałuszka et al., 2020), nitrogen isotope patterns (Holtgrieve et al., 2011), and many other geochemical signals (Waters et al., 2018, also see below). The stratigraphic distributions of biotic species can also be used as an important correlation tool, though typically lacking the globally isochronous markers required for the Anthropocene (Williams et al., 2018). Certainly, they can be used as further supportive evidence for the onset of the Anthropocene (e.g., Wilkinson et al., 2014) with unprecedented floral and faunal changes in response to a broad array of factors, including humaninduced climate change, pollution, deforestation, over-predation, introduction of domestic species and of non-indigenous species (spectacularly seen at the San Francisco Bay candidate site) as well as increased rates of species extinction and extirpation. The analysis of candidate GSSP lake and coastal sites includes an array of diatoms, foraminifera, ostracods, molluscs, pollen, phytoliths, zooplankton, testate amoebae as well as fish scales and emerging biomarkers (Fig. 11).

Given the scale of change registered in atmospheric carbon dioxide, methane, nitrates and atmospheric and ocean temperatures (Fig. 8) and many other planetary indicators when compared with the much smaller transitions across the subseries boundaries of the Holocene Series/Epoch (Fig. 9), it would be difficult, as argued by Waters et al. (2016), to rationalise a rank lower than series/epoch for the Anthropocene. In fact many of these parameters have 200 to $300 \%$ variances or larger compared with the Holocene Epoch and some represent phenomenological changes without precedent in the Holocene including a more acidic ocean and dispersal of novel materials (Syvitski et al., 2020). It has been proposed that defining the Anthropocene at system/ period rank, based upon the scale of species extinctions and increasing $\mathrm{CO}_{2}$ and temperatures, is more consistent with previous geological boundaries in the Phanerozoic (Bacon and Swindles, 2016). This is based upon an assumption that current extinction rates far exceed background geological levels and are on a trajectory towards a sixth mass extinction event (Barnosky et al., 2011), with previous such events used as the framework (if not specific markers) to justify establishment of boundaries at system/period (Ordovician-Silurian, Devonian-Carboniferous and Triassic-Jurassic) or erathem/era (PaleozoicMesozoic and Mesozoic-Cenozoic) ranks. However, this relies upon a near-future rather than current assessment of the situation. Many key Earth System parameters remain within the Quaternary envelope of variation and at present there is no clear argument that the Quaternary System/Period should be terminated.

\section{Final Considerations}

The Great Acceleration of the mid- $20^{\text {th }}$ century, from an array of Earth System and socio-economic indicators, was never intended to represent strict mathematical acceleration, but to reflect the striking increase in the magnitudes of these indicators, and the implication of such change (Steffen et al., 2004, 2015; Hibbard et al., 2007). Challenges to the concept of the Great Acceleration and hence of the Anthropocene (Nielsen, 2018a, b, and 2021a, b) do not consider the broader descriptive uses of the term 'acceleration', relying instead on curve-fitting methods that underestimate Earth System complexity and the implications of environmental loadings, and they misunderstand the process used in defining formal chronostratigraphic/geochronologic units.

Nielsen's (2018a, b, and 2021a) analyses usefully identify an inflection point (Fig. 3) for many of the Great Acceleration indicators. This point generally occurs at around 1960 or later (Table 1 of Nielsen, 2021a), which means that the highest growth rate observed must be just before that point in the time series. Evidence for the Great Acceleration, occurring in the decade or so following $\sim 1950$, is apparent within Nielsen's own analyses.

The notion of a 'Great Deceleration' in the mid- $20^{\text {th }}$ century (Nielsen, 2018a, b, and 2021a, b) is simply an expected consequence of a marked acceleration - in the real world, hyperbolic rises cannot be sustained over long durations (Smil, 2019). Importantly, a decelera- 
tion does not preclude continued increase in parameter growth, even if the growth rate is reduced. The consequent magnitude of increase among key indicators of the Earth System depicts a planetary trajectory that departed from the envelope of Holocene variability in the mid- $20^{\text {th }}$ century and argues for an Anthropocene at the rank of series/ epoch.

The Anthropocene from an Earth System perspective represents a complex planetary response to human impact involving lags, abrupt shifts and feedback loops. Nevertheless, there is strong evidence that around the mid- $20^{\text {th }}$ century many important Earth System parameters began strong trajectories away from Holocene norms (Steffen et al., 2016). Human impacts have a long and attenuated history that can be traced into the Late Pleistocene, but they did not become an overwhelming global environmental force until the mid- $20^{\text {th }}$ century.

From the wide array of proxy signals marking this striking Earth System change, a single primary stratigraphic marker must be chosen that will enable precise global correlation of the base of the Anthropocene. This signal has yet to be decided, but plutonium-239 is promising. It arises locally in 1945 CE from the atmospheric detonation of atomic (fission) devices, followed by a globally distributed and detectable signal in geological archives arising from the atmospheric testing of the much higher yield thermonuclear (fusion) devices from 1952 CE. If such a signal were adopted, it would be on the basis of stratigraphic utility alone, avowedly decoupled from the atomic age and all this connotes, albeit loosely linked by association with the overall rise in technology in the mid- $20^{\text {th }}$ century. Should it be chosen, this signal would be accompanied by many secondary stratigraphic markers more closely associated with the drivers of the Anthropocene.

We emphasize that the Great Acceleration cannot itself define a new unit within the Geological Time Scale: only a GSSP can do this. But it provides a crucial break of appropriate magnitude in the narrative of Earth history to justify inclusion of the Anthropocene at the rank of series/epoch beginning in the mid- $20^{\text {th }}$ century. The Great Acceleration has also left a constellation of stratigraphic signals, of which just one would serve as the primary guide to the GSSP. The others would provide abundant help in characterizing the Anthropocene and in practical recognition of its deposits.

The brief ( 70-year) duration for the Anthropocene and its usefulness require comment. Formal units of the Geological Time Scale are defined only by their base and no minimum duration is stipulated. The Anthropocene as a formal unit would be ongoing, as is presently the case for the Holocene Epoch and Late Holocene Subepoch (Meghalayan Age). The Holocene (duration presently 11,721 years) and its subepochs (duration as little as 3,464 years) are the briefest units for their rank, and attest to the needs and capabilities of exceptionally precise chronostratigraphy in the Quaternary (Head, 2019). The Anthropocene follows this tradition. The utility of these units cannot be doubted judging from citation figures. The term 'Late Holocene' was cited 654 times in the year 2020, and the term 'Anthropocene' 1,240 times in spite of its short duration and comparative novelty, as compared with 'Silurian' cited just 471 times (Clarivate's Web of Science). The final duration of the Anthropocene is obviously unknowable, and chronostratigraphy is based on the past, not the future. But it may be relevant that the IPCC (2021) considers some changes brought about by global warming, including sea-level rise, to be irreversible over hundreds to thousands of years. Perhaps more important than the duration of a formal unit in the Geological Time Scale is its stratigraphic content. Anthropocene deposits are exceptionally accessible and widely distributed around the world (Waters et al., 2018). They can be resolved using ultra-high precision radiometric dating, with laminated deposits potentially offering a year-by-year and even seasonal record of environmental change (Zalasiewicz et al., 2019b). Deposits may contain artifacts and can sometimes be tied to specific historical events (Hoffmann and Reicherter, 2014; Zalasiewicz et al., 2019a). Many of these stratigraphic signals will persist long into the future. The Anthropocene represents the overlap of geological, historical and instrumental time, its deposits capturing a rich, expansive and growing archive of our planet during a time of transformation.

The Anthropocene as a term, while lacking a long tradition, has rapidly gained extraordinary currency within the Earth Sciences and indeed throughout the sciences, social sciences and humanities (Zalasiewicz et al., 2021). As with the Holocene subdivisional terms, formalization of the Anthropocene will increase its utility and reduce confusion, at least within geology and cognate disciplines (Head, 2019). And as with the Meghalayan Stage, formalization will provide an isochronous base complementing the many diachronous time scales that already chart both human cultural activities and natural environmental changes.

\section{Acknowledgements}

We thank the Max Planck Institute for Chemistry, Mainz, where the late Paul Crutzen worked for many years, for elucidating Nielsen's (2021a) comment that Crutzen had endorsed the results of his work. Prof. Crutzen clarified that he did notice and acknowledge but did not review or endorse the paper 'The Great Deceleration and proposed alternative interpretation'. MJH acknowledges support from a Natural Sciences and Engineering Research Council of Canada Discovery Grant. Simon Turner kindly supplied Figure 11. This article has benefitted from stimulating ongoing discussions with colleagues in the Anthropocene Working Group. We are most grateful to two anonymous reviewers for their insightful comments and to Brian Marker as Associate Editor for helpful guidance.

\section{References}

Abram, N.A., McGregor, H.V., Tierney, J.E., Evans, M.N., McKay, N.P., Kaufman, D.S., and the PAGES 2k Consortium, 2016, Early onset of Industrial-era warming across the oceans and continents. Nature, v. 536, pp. 411-418.

Abram, N., Gattuso, J.-P., Prakash, A., Cheng, L., Chidichimo, M.P., Crate, S., Enomoto, H., Garschagen, M., Gruber, N., Harper, S., Holland, E., Kudela, R.M., Rice, J., Steffen, K., and von Schuckmann, K., 2019, Chapter 1. Framing and Context of the Report, pp. 73-129. In: Pörtner, H.-O., Roberts, D.C., Masson-Delmotte, V., et al. (Eds.), IPCC Special Report on the Ocean and Cryosphere in a Changing Climate. Intergovernmental Panel on Climate Change.

Archer, D., Eby, M., Brovkin, V., Ridgwell, A., Cao, L., Mikolajewicz, U., Caldeira, K., Matsumoto, K., Munhoven, G., Montenegro, A., and Tokos, K., 2009, Atmospheric lifetime of fossil fuel carbon dioxide. Annual Review of Earth and Planetary Sciences, v. 37, pp. 117-134, doi:10.1146/annurev.earth.031208.100206 
Bacon, K.L., and Swindles, G.T., 2016, Could a potential Anthropocene mass extinction define a new geological period? The Anthropocene Review, v. 3, pp. 208-217, doi:10.1177/2053019616666867

Bancone, C.E.P., Turner, S.D., Ivar do Sul, J.A., and Rose, N.L., 2020, The paleoecology of microplastic contamination. Frontiers of Environmental Science, v. 8, e574008.

Barnosky, A.D., Matzke, N., Tomiya, S., Wogan, G.O.U., Swartz, B., Quental, T.B., Marshall, C., McGuire, J.L., Lindsey, E.L., Maguire, K.C., Mersey, B., and Ferrer, E.A., 2011, Has the Earth's sixth mass extinction already arrived? Nature, v. 471, pp. 51-57, doi:10.1038/ nature09678

Bellwood, D.R., Hughes, T.P., Folke, C., and Nyström, M., 2004, Confronting the coral reef crisis. Nature, v. 429, pp. 827-833.

Broadgate, W., Gaffney, O., Deutsch, L., Ludwig, C., and Steffen, W., 2014, The Great Acceleration data. http://www.igbp.net

Caesar, L., McCarthy, G.D., Thornalley, D.J.R, Cahill, N., and Rahmstorf, S., 2021, Current Atlantic Meridional Overturning Circulation weakest in last millennium. Nature Geoscience, v. 14, pp. 118-120.

Chen, X., and Tung, K.-K., 2018, Global surface warming enhanced by weak Atlantic overturning circulation. Nature, v. 559, pp. 387-391.

Cheng, L., Trenberth, K.E., Gruber, N., Abraham, J.P., Fasullo, J.T., Li, G., Mann, M.E., Zhao, X., and Zhu, J., 2020, Improved estimates of changes in upper ocean salinity and the hydrological cycle. Journal of Climate, v. 33, pp. 10357-10381.

Cheng, L., Abraham, J., Trenberth, K.E., Fasullo, J., Boyer, T., Locarnini, R., Zhang, B., Yu, F., Wan, L., Chen, X., Song, X., Liu, Y., Mann, M. E., Reseghetti, F., Simoncelli, S., Gouretski, V., Chen, G., Mishonov, A., Reagan, J., and Zhu, L., 2021, Upper ocean temperatures hit record high in 2020. Advances in Atmospheric Science, v. 38, pp. 523-530.

Cheng, L., Trenberth, K.E., Fasullo, J., Boyer, T., Abraham, J., and Zhu, L., 2017, Improved estimates of ocean heat content from 1960 to 2015. Science Advances, v. 3, e1601545, doi:10.1126/sciadv.1601545

Clark, P.U., Shakun, J.D., Marcott, S.A., Mix, A.C., Eby, M., Kulp, S., Levermann, A., Milne, G.A., Pfister, P.L., Santer, B.D., Schrag, D.P., Solomon, S., Stocker, T.F., Strauss, B.H., Weaver, A.J., Winkelmann, R., Archer, D., Bard, E., Goldner, A., Lambeck, K., Pierrehumbert, R.T., and Plattner, G.-K., 2016, Consequences of twenty-first-century policy for multi-millennial climate and sea-level change. Nature Climate Change, v. 6, pp. 360-369, doi:10.1038/nclimate2923

Costanza, R., Graumlich, L., and Steffen, W. (Eds.), 2007, Sustainability or Collapse? An Integrated History and Future of People on Earth. Report of the 96th Dahlem Workshop on Integrated History and future Of People on Earth (IHOPE) Berlin, June 12-17, 2005. The MIT Press, Cambridge, Massachusetts, London, U.K., pp. i-xxii, 1-495.

Crutzen, P.J., 2002, Geology of Mankind. Nature, v. 415, p. 23.

Crutzen, P.J., and Stoermer, E.F., 2000, The "Anthropocene". Global Change Newsletter, v. 41, pp. 17-18.

Cui, Y., Schubert, B.A., and Jahren, A.H., 2020, A 23 m.y. record of low atmospheric $\mathrm{CO}_{2}$. Geology, v. 48, pp. 888-892, doi:10.1130/G47681.1

Fontanier, C., Mamo, B., Toucanne, S., Bayon, G., Schmidt, S., Deflandre, B., Dennielou, B., Jouet, G., Garnier, E., Sakai, S., Lamas, R.M., Duros, P., Toyofuku, T., Salé, A., Belleney, D., Bichon, S., Boissier, A., Chéron, S., Pitel, M., Roubi, A., Rovere, M., Grémare, A., Dupré, S., and Jorry, S.J., 2018, Are deep-sea ecosystems surrounding Madagascar threatened by land-use or climate change? Deep-Sea Research Part 1, v. 131, pp. 93-100.

Gałuszka, A., Migaszewski, Z.M., and Rose, N.L., 2020, A consideration of polychlorinated biphenyls as a chemostratigraphic marker of the Anthropocene. The Anthropocene Review, v. 7, pp. 138-158.

Gould, W.J., and Cunningham, S.A., 2021, Global-scale patterns of observed sea surface salinity intensified since the 1870 s. Communications Earth and Environment, 2:76. doi:10.1038/s43247-021-00161-3

Han, Y.M., An, Z.S., and Cao, J.J., 2017, The Anthropocene: A potential stratigraphic definition based on black carbon, char, and soot records. In: DellaSala, D., and Goldstein, M.I. (Eds.), Encyclopedia of the
Anthropocene, vol. 1. Elsevier, Oxford, doi:10.1016/B978-0-12-4095489.10001-6

Haustein, K., Allen, M.R., Forster, P.M., Otto, F.E.L., Mitchell, D.M., Matthews, H.D., and Frame, D.J., 2017, A real-time global warming index. Scientific Reports v. 7, 15417.

Haustein, K., Otto, F.E.L., Venema, V., Jacobs, P., Cowtan, K., Hausfather, Z., Way, R.G., White, B., Subramanian, A., and Schurer, A.P., 2019, A limited role for unforced internal variability in twentieth-century warming. Journal of Climate, v. 32, pp. 4893-4916.

Head, M.J., 2019, Formal subdivision of the Quaternary System/Period: present status and future directions. Quaternary International, v. 500, pp. 32-51, doi:10.1016/j.quaint.2019.05.018

Head, M.J., Pillans, B., and Zalasiewicz, J.A., 2021, Formal ratification of subseries/subepochs for the Pleistocene Series/Epoch of the Quaternary System/Period. Episodes, doi:10.18814/epiiugs/2020/020084

Hibbard, K.A., Crutzen, P.J., Lambin, E.F., Liverman, D.M., Mantua N.J., McNeill, J.R., Messerli, B., and Steffen, W., 2007, Decadal-scale interactions of humans and the environment. In: Costanza, R., Graumlich, L. and Steffen, W. (Eds.), Sustainability or Collapse? An Integrated History and Future of People on Earth. The MIT Press, Cambridge, Massachusetts, London, U.K., pp. 341-375.

Hiddink, J.G., Jennings, S., Kaiser, M.J., Queirós, A.M., Duplisea, D.E., and Piet, G.J., 2006, Cumulative impacts of seabed trawl disturbance on benthic biomass, production, and species richness in different habitats. Canadian Journal of Fisheries and Aquatic Sciences, v. 63, pp. 721-736.

Hoffmann, G., and Reicherter, K., 2014, Reconstructing Anthropocene extreme flood events by using litter deposits. Global Planetary Change, v. 123, pp. 22-28.

Holtgrieve, G.W., Schindler, D.E., Hobbs, W.O., Leavitt, P.R., Ward, E.J., Bunting, L., Chen, G., Finney, B.P., Gregory-Eaves, I., Holmgren, S., and Lisac, M.J., 2011, A coherent signature of anthropogenic nitrogen deposition to remote watersheds of the northern hemisphere. Science, v. 334, pp. 1545-1548.

Hughes, T.P., Barner, M.K., Bellwood, D.R., Cinner, J.E., Cumming, G.S., Jackson, J.B.C., Kleypas, J., van de Leemput, I.A., Lough, J.M., Morrison, T.H., Palumbi, S.R., van Nes, E.H., and Scheffer, M., 2017, Coral reefs in the Anthropocene. Nature, v. 546, pp. 82-90.

International Energy Agency, 2021, https://www.iea.org/data-and-statistics/charts/global-cement-production-2010-2019

IPBES, 2019, Summary for policymakers of the global assessment report on biodiversity and ecosystem services of the Intergovernmental Science-Policy Platform on Biodiversity and Ecosystem Services. Díaz, S., Settele, J., Brondízio, E.S., Ngo, H.T., Guèze, M., Agard, J., Arneth, A., Balvanera, P., Brauman, K.A., Butchart, S.H.M., Chan, K.M.A., Garibaldi, L.A., Ichii, K., Liu, J., Subramanian, S.M., Midgley, G.F., Miloslavich, P., Molnár, Z., Obura, D., Pfaff, A., Polasky, S., Purvis, A., Razzaque, J., Reyers, B., Chowdhury, R.R., Shin, Y.J., Visseren-Hamakers, I.J., Willis, K.J., and Zayas, C.N. (Eds.), Intergovernmental SciencePolicy Platform on Biodiversity and Ecosystem Services (IPBES) secretariat, Bonn, Germany, 56 pp. doi:10.5281/zenodo. 3553579

IPCC, 2021, Climate Change 2021: The Physical Science Basis. Contribution of Working Group I to the Sixth Assessment Report of the Intergovernmental Panel on Climate Change. Masson-Delmotte, V., Zhai, P., Pirani, A., Connors, S.L., Péan, C., Berger, S., Caud, N., Chen Y., Goldfarb, L., Gomis, M.I., Huang, M., Leitzell, K., Lonnoy, E., Matthews, J.B.R., Maycock, T.K., Waterfield, T., Yelekçi, O., Yu R., and Zhou, B. (Eds.). Cambridge University Press, in press. https://www.ipcc.ch/ report/ar6/wg1/downloads/report/IPCC_AR6_WGI_Full_Report.pdf

Johnson, G.C., and Lyman, J.M., 2020, Warming trends increasingly dominate global oceans. Nature Climate Change, v. 10, pp. 757-761.

Krausmann, F., Lauk, C., Haas, W., and Wiedenhofer, D., 2018, From resource extraction to outflows of wastes and emissions: The socioeconomic metabolism of the global economy, 1900-2015. Global Environmental Change, v. 52, pp. 131-140. 
Lear, C.H., Anand, P., Blenkinsop, T., Foster, G.L., Gagen, M., Hoogakker, B., Larter, R.D., Lunt, D.J., McCave, I.N., McClymont, E., Pancost, R.D., Rickaby, R.E.M., Schultz, D.M., Summerhayes, C., Williams, C.J.R., and Zalasiewicz, J., 2020, Geological Society of London Scientific Statement: what the geological record tells us about our present and future climate. Journal of the Geological Society, v. 178, jgs2020-239, doi:10.1144/jgs2020-239

Lindsey, R., 2020, Climate change: atmospheric carbon dioxide. NOAA Climate.gov. https:/www.climate.gov/news-features/understandingclimate/climate-change-atmospheric-carbon-dioxide [accessed 25 November, 2020]

Loulergue, L., Schilt, A., Spahni, R., Masson-Delmotte, V., Blunier, T., Lemieux, B., Barnola, J.-M., Raynaud, D., Stocker, T.F., and Chappellaz, J., 2008, Orbital and millennial-scale features of atmospheric $\mathrm{CH}_{4}$ over the past 800,000 years. Nature, v. 453, pp. 383-386, doi:10.1038/ nature 06950

Maddison project database, 2020. https:/www.rug.nl/ggdc/historicaldevelopment/maddison/releases/maddison-project-database-2020

Mazor, T., Pitcher, C.R., Rochester, W., Kaiser, M.J., Hiddink, J.G., Jennings, S., Amoroso, R., McConnaughey, R.A., Rijnsdorp, A.D., Parma, A.M., Suuronen, P., Collie, J., Sciberras, M., Atkinson, L., Durholtz, D., Ellis, J.R., Bolam, S.G., Schratzberger, M., Couce, E., Eggleton, J., Garcia, C., Kainge, P., Paulus, S., Kathena, J.N., Gogina, M., van Denderen, P.D., Keller, A.A., Horness, B.H., and Hilborn, R., 2021, Trawl fishing impacts on the status of seabed fauna in diverse regions of the globe. Fish and Fisheries, v. 22, pp. 72-86.

McNeill, J.R., 2000, Something new under the Sun: an environmental history of the twentieth-century world. Norton, New York, 448 pp.

McNeill, J.R., and Engelke, P., 2014, The Great Acceleration: An environmental history of the Anthropocene since 1945. Harvard University Press, Cambridge, Massachusetts, 288 pp.

Medhaug, I., Stolpe, M., Fischer, E., and Knutti, R., 2017, Reconciling controversies about the 'global warming hiatus'. Nature, v. 545, pp. 41-47.

Nielsen, R.W., 2017, Application of differential equations in projecting growth trajectories. Journal of Economic Bibliography, v. 4, pp. 203-221.

Nielsen, R.W., 2018a, The Great Deceleration in human activities and impacts. Journal of Economic and Social Thought, v. 5, pp. 295-330.

Nielsen, R.W., 2018b, Mathematical analysis of anthropogenic signatures: The Great Deceleration. Open-access e-print archive, p. 1-41. https://arxiv.org/pdf/1803.06935

Nielsen, R.W., 2021a, The Great Deceleration and proposed alternative interpretation of the Anthropocene. Episodes, v. 44, pp. 107-114; and supplement, pp. 1-8.

Nielsen, R.W., 2021b, Anthropogenic data question the concept of the Anthropocene as a new geological epoch. Episodes, doi:10.18814/epiiugs/2021/021020; and supplement, pp. 1-7.

NOAA Global Monitoring Laboratory, 2021. https://www.esrl.noaa.gov/ gmd/ccgg/trends/gl_data.html [accessed 24 March, 2021]

Our World in Data, 2020, Methane $\left(\mathrm{CH}_{4}\right)$ atmospheric concentration. https://ourworldindata.org/grapher/ch4-concentration [accessed 18 October, 2020]

Pauly, D., and Zeller, D., 2016, Catch reconstructions reveal that global marine fisheries catches are higher than reported and declining. Nature Communications, 7:10244, doi: 10.1038/ncomms10244

Pauly, D., Alder, J., Bennett, E., Christensen, V., Tyedmers, P., and Watson, R., 2003, The future for fisheries. Science, v. 302, pp. 1359-1361.

Pfister, C., 1992, Das 1950er Syndrom. Der Energieverbrauch unserer Zivilisation in historischer Perspektive. Natur und Mensch, v. 34, pp. $1-4$.

Pfister, C., 1994, Das 1950er-Syndrom. Die Epochenschwelle der MenschUmwelt-Beziehung zwischen Industriegesellschaft und Konsumsgesellschaft. Gaia, v. 3, pp. 71-90.

Polanyi, K., 1944, The Great Transformation. First edition. Farrar and Rinehart, New York, 305 pp.
Qin, M., Dai, A., and Hua, W., 2020, Aerosol-forced multidecadal variations across all ocean basins in models and observations since 1920. Science Advances, v. 6, eabb0425.

Remane, J., Bassett, M.G., Cowie, J.W., Gohrbandt, K.H., Lane, H.R., Michelsen, O., Wang, N., with the cooperation of members of ICS, 1996, Revised guidelines for the establishment of global chronostratigraphic standards by the International Commission on Stratigraphy (ICS). Episodes, v. 19, pp. 77-81.

Reuer, M.K., and Weiss, D.J., 2002, Anthropogenic lead dynamics in the terrestrial and marine environment. Philosophical Transactions of the Royal Society London A, v. 360, pp. 2889-2904, doi:10.1098/rsta.2002. 1095

Ritchie, H., and Roser, M., 2020, $\mathrm{CO}_{2}$ and greenhouse gas emissions. Our World in Data, https://ourworldindata.org/co2-and-other-greenhousegas-emissions.

Rose, N.L., 2015, Spheroidal carbonaceous fly-ash particles provide a globally synchronous stratigraphic marker for the Anthropocene. Environmental Science and Technology, v. 49, pp. 4155-4162.

Salvador, A. (Ed.), 1994, International Stratigraphic Guide: A Guide to Stratigraphic Classification, Terminology, and Procedure (2nd Edition). International Subcommission on Stratigraphic Classification of IUGS International Commission on Stratigraphy and The Geological Society of America. Boulder, Colorado.

Smil, V., 2019, Growth: From Microorganisms to Megacities. MIT Press, $634 \mathrm{pp}$.

Smith, D.M., Booth, B.B.B., Dunstone, N.J., Eade, R., Hermanson, L., Jones, G.S., Scaife, A.A., Sheen, K.L., and Thompson, V., 2016, Role of volcanic and anthropogenic aerosols in the recent global surface warming slowdown. Nature Climate Change v. 6, pp. 936-940, doi:10.1038/nclimate3058

Steffen, W., Crutzen, P., and McNeill, J., 2007, The Anthropocene: Are humans now overwhelming the great forces of Nature? Ambio: A Journal of Environment and Society, v. 36, pp. 614-621.

Steffen, W., Sanderson, A., Tyson, P.D., Jäger, J., Matson, P., Moore III, B., Oldfield, F., Richardson, K., Schellnhuber, H.-J., Turner II, B.L., and Wasson, R.J., 2004, Global Change and the Earth System: A Planet Under Pressure. The IGBP Book Series, Springer-Verlag, Berlin, Heidelberg, New York. i-xii + 1-336 p.

Steffen, W., Grinevald, J., Crutzen, P., and McNeill, J., 2011, The Anthropocene: Conceptual and historical perspectives. Philosophical Transactions of the Royal Society A, v. 369, pp. 842-867, doi:10.1098/ rsta.2010.0327

Steffen, W., Broadgate, W., Deutsch, L., Gaffney, O., and Ludwig, C., 2015, The trajectory of the Anthropocene: The Great Acceleration. The Anthropocene Review, v. 2, pp. 81-98, doi:10.1177/2053019614564785

Steffen, W., Leinfelder, R., Zalasiewicz, J., Waters, C.N., Williams, M., Summerhayes, C., Barnosky, A.D., Cearreta, A., Crutzen, P., Edgeworth, M., Ellis, E.C., Fairchild, I.J., Gałuszka, A., Grinevald, J., Haywood, A., Ivar do Sul, J., Jeandel, C., McNeill, J.R., Odada, E., Oreskes, N., Revkin, A., Richter, D. deB, Syvitski, J., Vidas, D., Wagreich, M., Wing S.L., Wolfe, A.P., and Schellnhuber, H.J., 2016, Stratigraphic and Earth System approaches to defining the Anthropocene. Earth's Future 4, doi:10.1002/2016EF000379

Sumaila, U.R., Bellmann, C., and Tipping, A., 2016, Fishing for the future: An overview of challenges and opportunities. Marine Policy, v. 69, pp. 173-180.

Summerhayes, C.P., 2008, International collaboration in Antarctica: the International Polar Years, the International Geophysical Year, and the Scientific Committee on Antarctic Research. Polar Record, v. 44, pp. 321-335.

Syvitski, J., Waters, C.N., Day, J., Milliman, J.D., Summerhayes, C., Steffen, W., Zalasiewicz, J., Cearreta, A., Gałuszka, A., Hajdas, I., Head, M.J., Leinfelder, R., McNeill, J.R., Poirier, C., Rose, N.L., Shotyk, W., Wagreich, M., and Williams, M., 2020, Extraordinary human energy consumption and resultant geological impacts beginning around 1950 
CE initiated the proposed Anthropocene Epoch. Communications Earth and Environment, v. 1, 32, doi:10.1038/s43247-020-00029-y

Syvitski, J., Restrepo Ángel, J., Saito, Y., Overeem, I., Vörösmarty, C., Wang, H., and Olago, D., in press, Earth's sediment cycle during the Anthropocene. Nature Reviews Earth and Environment.

Thrush, S.F., Ellingsen, K.E., and Davis, K., 2016, Implications of fisheries impacts to seabed biodiversity and ecosystem-based management. ICES Journal of Marine Science, v. 73: i44-i50, doi:10.1093/icesjms/ fsv114

Turney, C.S.M., Palmer, J., Maslin, M.A., Hogg, A., Fogwill, C.J., Southon, J., Fenwick, P., Helle, G., Wilmshurst, J.M., McGlone, M., Bronk Ramsey, C., Thomas, Z., Lipson, M., Beaven, B., Jones, R.T., Andrews, O., and Hua, Q., 2018, Global peak in atmospheric radiocarbon provides a potential definition for the onset of the Anthropocene Epoch in 1965. Scientific Reports, v. 8, 3293, doi:10.1038/s41598-018-20970-5

Van Breedam, J., Goelzer, H., and Huybrechts, P., 2020, Semi-equilibrated global sea-level change projections for the next 10000 years. Earth System Dynamics, v. 11, pp. 953-976, doi:10.5194/esd-11-9532020

Walker, M., Johnsen, S., Rasmussen, S.O., Popp, T., Steffensen, J.-P., Gibbard, P., Hoek, W., Lowe, J., Andrews, J., Björck, S., Cwynar, L.C., Hughen, K., Kershaw, P., Kromer, B., Litt, T., Lowe, D.J., Nakagawa, T., Newnham, R., and Schwander, J., 2009, Formal definition and dating of the GSSP (Global Stratotype Section and Point) for the base of the Holocene using the Greenland NGRIP ice core, and selected auxiliary records. Journal of Quaternary Science, v. 24, pp. 3-17, doi:10.1002/ jqs. 1227

Walker, M., Head, M.J., Berkelhammer, M., Björck, S., Cheng, H., Cwynar, L., Fisher, D., Gkinis, V., Long, A., Lowe, J., Newnham, R., Rasmussen, S., and Weiss, H., 2018, Formal ratification of the subdivision of the Holocene Series/Epoch (Quaternary System/Period): two new Global Boundary Stratotype Sections and Points (GSSPs) and three new stages/subseries. Episodes, v. 41, pp. 213-223, doi:10.18814/epiiugs/2018/018016

Walker, M., Head, M.J., Berkelhammer, M., Björck, S., Cheng, H., Cwynar, L., Fisher, D., Gkinis, V., Long, A., Lowe, J., Newnham, R., Rasmussen, S., and Weiss, H., 2019, Subdividing the Holocene Series/ Epoch: formalisation of stages/ages and subseries/subepochs, and designation of GSSPs and auxiliary stratotypes. Journal of Quaternary Science, v. 34, pp. 173-186, doi:10.1002/jqs.3097

Waters C.N., and Zalasiewicz J., 2018, Concrete: The most abundant novel rock type of the Anthropocene. In: DellaSala, D.A., and Goldstein, M.I. (Eds.), The Encyclopedia of the Anthropocene, vol. 1, p. 75-85. Elsevier, Oxford.

Waters, C.N., Syvitski, J.P.M., Gałuszka, A., Hancock, G.J., Zalasiewicz, J., Cearreta, A., Grinevald, J., Jeandel, C., McNeill, J.R., Summerhayes, C., and Barnosky, A., 2015, Can nuclear weapons fallout mark the beginning of the Anthropocene Epoch? Bulletin of the Atomic Scientists, v. 71, pp. 46-5, doi:10.1177/0096340215581357

Waters, C.N., Zalasiewicz, J., Summerhayes, C., Barnosky, A.D., Poirier, C., Gałuszka, A., Cearreta, A., Edgeworth, M., Ellis, E.C., Ellis, M., Jeandel, C., Leinfelder, R., McNeill, J.R., Richter, D. deB., Steffen, W., Syvitski, J., Vidas, D., Wagreich, M., Williams, M., An, Z., Grinevald, J., Odada, E., Oreskes, N., and Wolfe, A.P., 2016, The Anthropocene is functionally and stratigraphically distinct from the Holocene. Science, v. 351, aad2622. doi:10.1126/science.aad2622

Waters, C.N., Zalasiewicz, J., Summerhayes, C., Fairchild, I.J., Rose, N.L., Loader, N.J., Shotyk, W., Cearreta, A., Head, M.J., Syvitski, J.P.M., Williams, M., Wagreich, M., Barnosky, A.D., An, Z., Leinfelder, R., Jeandel, C., Gałuszka, A., Ivar do Sul, J.A., Gradstein, F., Steffen, W., McNeill, J.R., Wing, S., Poirier, C., and Edgeworth, M., 2018, Global Boundary Stratotype Section and Point (GSSPs) for the Anthropocene Series: Where and how to look for a potential candidates. Earth-Science Reviews, v. 178, pp. 379-429, doi:10.1016/j.earscirev.2017.12.016
Waters, C.N., Hajdas, I., Jeandel, C., and Zalasiewicz, J., 2019, 5.8 Artificial radionuclude fallout signals. In: Zalasiewicz, J., Waters, C.N., Williams, M., and Summerhayes, C. (Eds.), The Anthropocene as a Geological Time Unit. A Guide to the Scientific Evidence and Current Debate. Cambridge University Press, Cambridge, U.K., pp. 192-199.

Willeit, M., Ganopolski, A., Calov, R., and Brovkin, V., 2019, Mid-Pleistocene transition in glacial cycles explained by declining $\mathrm{CO}_{2}$ and regolith removal. Science Advances, v. 5, eaav7337, doi:10.1126/ sciadv.aav 7337

Wilkinson, I.P., Poirier, C, Head, M.J., Sayer, C.D., and Tibby, J., 2014, Microbiotic signatures of the Anthropocene in marginal marine and freshwater palaeoenvironments. In: Waters, C.N., Zalasiewicz, J.A., Williams, M. et al. (Eds.), A Stratigraphical Basis for the Anthropocene. Geological Society, London, Special Publications, v. 395, pp. 185-219, doi:10.1144/SP395.14

Williams, M., Zalasiewicz, J., Waters, C., Himson, S., and Summerhayes, C., 2018, The palaeontological record of the Anthropocene. Geology Today, v. 34 (5), pp. 188-193, doi:10.1111/gto.12246

Zalasiewicz, J., and Waters, C.N., 2019, 5.2 Carbon. In: Zalasiewicz, J., Waters, C.N., Williams, M., and Summerhayes, C. (Eds.), The Anthropocene as a Geological Time Unit. A Guide to the Scientific Evidence and Current Debate. Cambridge University Press, Cambridge, U.K., pp. $160-165$.

Zalasiewicz, J., Williams, M., and Waters, C.N., 2014, Can an Anthropocene series be defined and recognised? In: Waters, C.N., Zalasiewicz, J., Williams, M., Ellis, M.A., Snelling, A. (Eds.), A Stratigraphical Basis for the Anthropocene, Geological Society, London, Special Publications 395, pp. 39-53.

Zalasiewicz, J., Waters, C.N., Williams, M., Barnosky, A.D., Cearreta, A., Crutzen, P., Ellis, E., Ellis, M.A., Fairchild, I.J., Grinevald, J., Haff, P.K., Hajdas, I., Leinfelder, R., McNeill, J., Odada, E.O., Poirer, C., Richter, D., Steffen, W., Summerhayes, C., Syvitski, J.P.M., Vidas, D., Wagerich, M., Wing, S.L., Wolfe, A.P., Zhisheng, A., and Oreskes, N., 2015, When did the Anthropocene begin? A mid-twentieth century boundary level is stratigraphically optimal. Quaternary International, v. 383, pp. 196-203.

Zalasiewicz, J., Waters, C.N., Ivar do Sul, J., Corcoran, P.L., Barnosky, A.D., Cearreta, A., Edgeworth, M., Gałuszka, A., Jeandel, C., Leinfelder, R., McNeill, J.R., Steffen, W., Summerhayes, C., Wagreich, M., Williams, M., Wolfe. A.P., and Yonan, Y., 2016, The geological cycle of plastics and their use as a stratigraphic indicator of the Anthropocene. Anthropocene, v. 13, pp. 4-17, doi:10.1016/j.ancene.2016.01.002

Zalasiewicz, J., Waters, C.N., and Head, M.J., 2017a, Anthropocene: its stratigraphic basis. Nature, v. 541, p. 289, doi:10.1038/541289b

Zalasiewicz, J., Waters, C.N., Summerhayes, C.P., Wolfe, A.P., Barnosky, A.D., Cearreta, A., Ellis, E., Fairchild, I., Gałuszka, A., Haff, P., Hajdas, I., Head, M.J., Jeandel, C., Leinfelder, R., McNeill, J., Neal, C., Steffen, W., Syvitski, J., Wagreich, M., and Williams, M., 2017b, The Working Group on the Anthropocene: Summary of evidence and interim recommendations. The Anthropocene, v. 19, pp. 55-60, doi:10.1016/ j.ancene.2017.09.001

Zalasiewicz, J., Steffen, W., Leinfelder, R., Williams, M. and Waters, C.N., 2017c, Petrifying Earth process: the stratigraphic imprint of key Earth System parameters in the Anthropocene. Theory, Culture \& Society, v. 34, pp. 83-104.

Zalasiewicz, J., Waters, C., Head, M.J., Steffen, W., Syvitski, J.P., Vidas, D., Summerhayes, C., and Williams, M., 2018, The geological and Earth System reality of the Anthropocene. Current Anthropology, v. 59, pp. 220-223.

Zalasiewicz, J., Waters, C.N., Williams, M., and Barnosky, A., 2019a, Chapter 4.2 Technofossil Stratigraphy, p. 144-147. In: Zalasiewicz, J., Waters, C.N., Williams, M., Summerhayes, C. (Eds.), The Anthropocene as a Geological Time Unit: A Guide to the Scientific Evidence and Current Debate. Cambridge University Press, Cambridge, U.K.

Zalasiewicz, J., Waters, C.N., Williams, M., and Summerhayes, C. (Eds.), 
2019b, The Anthropocene as a Geological Time Unit. A Guide to the Scientific Evidence and Current Debate. Cambridge University Press, Cambridge, U.K.

Zalasiewicz, J., Waters, C.N., Ellis, E.C., Head, M.J., Vidas, D., Steffen, W., Thomas, J.A., Horn, E., Summerhayes, C.P., Leinfelder, R., McNeill, J.R., Gałuszka, A., Williams, M., Barnosky, A.D., Richter, D. deB., Gibbard, P.L., Syvitski, J., Jeandel, C., Cearreta, A., Cundy, A.B., Fairchild, I.J., Rose, N.L., Ivar do Sul, J.A., Shotyk, W., Turner, S., Wagreich, M., and Zinke, J., 2021, The Anthropocene: comparing its

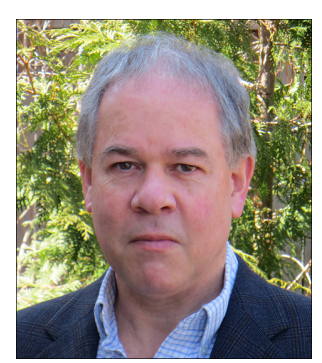

Martin J. Head is a stratigrapher and Professor of Earth Sciences at Brock University, Canada, and is a status-only full professor at the University of Toronto, Canada. He is currently Vice-Chair of the International Subcommission on Quaternary Stratigraphy (SQS), having served as its Chair (2012-2020), and is Co-Convener of its Working Group on the Middle-Upper Pleistocene Subseries Boundary. $\mathrm{He}$ is concurrently a voting member of the SQS Working Group on the Anthropocene and of the International Subcommission on Stratigraphic Classification, and an advisory board member of the INQUA Stratigraphy and Chronology Commission (SACCOM).

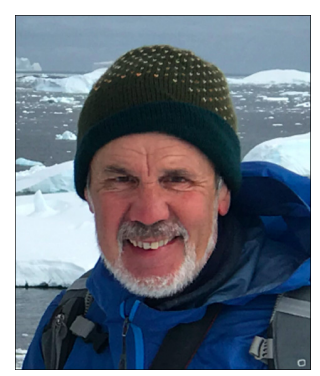

Will Steffen is an Earth System scientist. He is a Councillor on the publicly-funded Climate Council of Australia that delivers independent expert information about climate change. He is also an Emeritus Professor at the Australian National University (ANU), Canberra; a Senior Fellow at the Stockholm Resilience Centre, Sweden; and a member of the Anthropocene Working Group. From 1998 to mid-2004, Steffen was Executive Director of the International Geosphere-Biosphere Programme, based in Stockholm. His research interests span a broad range within Earth System science, with an emphasis on sustainability and climate change. meaning in geology (chronostratigraphy) with conceptual approaches arising in other disciplines. Earth's Future, v. 9, e2020EF001896, doi:10.1029/2020EF001896

Zhang, Y.G., Pagani, M., Liu, Z., Bohaty, S.M., and DeConto, R., 2013, A 40-million-year history of atmospheric $\mathrm{CO}_{2}$. Philosophical Transactions of the Royal Society: A, Mathematical, Physical and Engineering Sciences, v. 371, 20130096, pp. 1-20, doi:10.1098/rsta.2013.009=

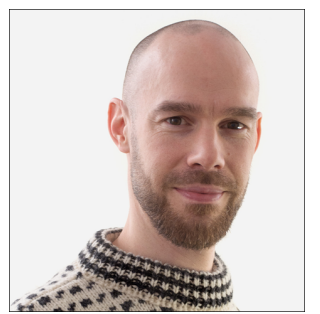

David Fagerlind is a $\mathrm{PhD}$ student in Sustainability Science at the Stockholm Resilience Centre, Stockholm University, Sweden. His research spans a wide range of topics related to how human activities affect the Earth System, with an emphasis on the potential of alternative economic models such as green-, circular- and bio- in contributing to sustainable development. 